\title{
Sosyal Medya Aracılığıyla Turizm Deneyimi Paylaşma Motivasyonunu Etkileyen Faktörlerin İncelenmesi ${ }^{1}$
}

\section{iD Aykut Oğuz ALGUER ${ }^{2}$ (iD) Beykan ÇİZEL ${ }^{3}$}

\section{Özet}

Günümüzde milyonlarca insan, internetin ilişkisel bileşenlerine katılmak için sosyal ağ hizmetlerini kullanmaktadır. Sosyal alışveriş olarak bilinen deneyim paylaşımı da bu ağların önemli bir bölümünü oluşturmaktadır. Turistler aktif birer sosyal ağ katılımcısı olarak, kendi oluşturdukları içerikleri diğer kullanıcılara paylaşmakta ve deneyimlerini şekillendirmektedir. Bu çalışmanın amacı, sosyal medya aracıllğıyla turizm deneyimi paylaşma motivasyonunu etkileyen faktörlerin incelenmesidir. Araştırmada veriler, 2019 Temmuz ve Ağustos aylarında Antalya ilinde turizm deneyimi yaşamış 501 yerli ziyaretçiden Antalya Uluslararası Havalimanı'ndan ayrılışları sırasında, kolayda örnekleme yöntemiyle toplanmıştır. İlişki analizleri ile araştırma hipotezleri test edilmiş ve sonuçlar ilişkisel pazarlama kuramı ve sosyal destek kuramı bakış açısı ile tartışılmış ve yorumlanmıştır. İlişki kalitesi ve sosyal desteğin deneyim paylaşım motivasyonunu pozitif yönde etkilediği ve göreceli olarak bu ilişkide ilişki kalitesi etkisinin daha güçlü olduğu saptanmıştır. Çalışma sonuçlarının alanda yer alan araştırmacı ve uygulamacılara faydalar sağlayacağı ümit edilmektedir.

Anahtar kelimeler: Sosyal medya, turizm deneyimi, paylaşım motivasyonu, sosyal destek, ilişki kalitesi

JEL Kodu/Code: L83.

\section{Investigation of Factors Affecting the Motivation to Share Tourism Experience Through Social Media}

\section{Abstract}

Today, millions of people use social networking services to participate in the relational components of the internet. Experience sharing, known as social shopping, also constitutes an important part of these networks. As active social network participants, tourists share their own content with other users and shape their experiences. The aim of this study is to examine the factors affecting the motivation to share tourism experiences through social media. In the research, data were collected by convenience sampling method from 501 domestic visitors who had tourism experience in Antalya in July and August 2019, during their departure from Antalya International Airport. Relationship analysis and research hypotheses were tested and the results were discussed and interpreted from the perspective of relationship marketing theory and social support theory. It has been determined that the relationship quality and social support positively affect the motivation to share experience, and the relationship quality effect is relatively stronger in this relationship. It is hoped that the results of the study will provide benefits to researchers and practitioners in the field.

Keywords: Social media, tourism experience, motivation to share, social support, relationship quality

Referans/Citation: Alguer, A. O. \& Çizel, B. (2021). Sosyal Medya Aracılı̆̆ıyla Turizm Deneyimi Paylaşma Motivasyonunu Etkileyen Faktörlerin İncelenmesi, Journal of Hospitality and Tourism Issues, Vol. 3, No.2, 153175.

\footnotetext{
${ }^{1}$ Sosyal medya aracılığıyla turizm deneyimi paylaşma motivasyonunu etkileyen faktörlerin incelenmesi isimli çalışma "2020'li kayıtlı yüksek lisans tezimden türetilmiş olup özgünlük ve benzerlik olarak tez kapsamında kalınmıştır".

${ }^{2}$ Doktora öğrencisi, Turizm İşletmeciliği, Akdeniz Üniversitesi, aykutoguz3407@gmail.com, Orcid ID: 0000-0001-79516402

${ }^{3}$ Prof. Dr., Turizm Fakültesi, Akdeniz Üniversitesi, beykan@akdeniz.edu.tr, Orcid ID: 0000-0003-0474-9222
} 


\section{GİRIŞ}

Günümüzde sosyal medya, kullanıcılara yeni etkileşim imkânları sağlamaktadır (Xiang \& Gretzel, 2010). Geniş bir kullanıcı tabanına sahip olmakla birlikte; "beğeniler", "yorumlar" ve "içerik oluşturma" gibi türlü aktivitelerle insanları birbirine bağlamaktadır. Turistler de sosyal medyada birbirleriyle etkileşime girmekte ve kendi oluşturdukları içerikleri çeşitli uygulamalar ve internet siteleri aracılığıyla diğer insanlara sunmaktadır. Bu içerikler özellikle turizmin doğasında yer alan; deneyim biriktirme, deneyim yaşama ve deneyimleri paylaşma noktasında sosyal ağ kullanıcısı turistler ve turistik hizmet sağlayıcıları açısından büyük önem taşımaktadır. Bu önemi fark eden araştırmacılar, insanların davranış niteliklerini merkezlerine almakta ve deneyim/bilgi paylaşımı konusunda tetikleyici olan iki çeşit motivasyonu ileri sürmektedirler (Hsu \& Lin, 2008; Chang \& Chuang, 2011). Bunlar; kişisel itibar kazanma istekleri ve başka insanlara yardımda bulunma çabalarından kaynaklanan faaliyetlerdir. Munar \& Jacobsen tarafından yapılan çalışmada, sosyal medyada turizm deneyimi paylaşımının; bireysel/benmerkezci ve toplumla ilgili motivasyonlardan yola çıkarak gerçekleştirildiği anlaşılmaktadır (Munar \& Jacobsen, 2014). Ancak ilgili literatür incelendiğinde bu motivasyonlara sahip turistlerin deneyimleri üzerinden oluşturdukları içerikleri paylaşmaları konusunda, onları paylaşımda bulunmaya yönelten unsurların neler olduğu konusunda çok fazla araştırma yoktur. Bu nedenle hangi faktörlerin sosyal medya aracılığıyla deneyim paylaşımları üzerinde, ne derece etkiye sahip olduğunu anlamak önem taşımaktadır.

Turistlerin sosyal medya aracılığıyla deneyim paylaşımları, tatilleriyle ilgili bilgileri bir veya daha fazla sosyal medya platformunda başkalarıyla paylaşma faaliyetleridir. Bireysel ve sosyal motivasyonla eyleme dönüştüğü bilinen bu paylaşım öncüllerinin sosyal destek ve ilişki kalitesi olduğu düşünülmektedir. Bunun nedeni sosyal destek ve ilişki kalitesinin sosyal medya ile ilgili çevrimiçi bilgi ve deneyim paylaşımları üzerine yapılan çalışmalarda sıklıkla kullanılmış olmasıdır (Hajli, 2014; Liang vd., 2011; Göker \& Keskin, 2015).

Literatürde sosyal medya aracılığıyla bilgi ve deneyim paylaşımına ilişkin çalışmalar mevcuttur (Munar \& Jacobsen, 2014; Wang vd., 2014; Chiu vd., 2006; Ghaisani vd., 2014). Wang vd. (2011) sosyal desteğin turizm deneyimleri ve psikolojik çıkarımlar arasındaki ilişkide etkisinin ve Kim ve Tussyadiah (2013) sosyal destek yoluyla turistlerin özel duygu-düşünceler ile turizm deneyimlerini paylaşabildiklerini incelemişlerdir. İlişki kalitesi ile ilgili; ilişkisel anlamda güven, ilişkiyi sürdürme çabası anlamında bağlılık ve sürdürülen ilişkiden duyulan memnuniyete ilişkin çalışmalar önemli bulgular sağlamıştır (Liang vd., 2011; Lakey \& Cohen, 2000; Pentina vd., 2013; Wang vd., 2002). Görüldüğü üzere turistlerin sosyal ağlarda deneyim paylaşmalarının nelerden kaynaklandığı konusu farklı faktörler ve motivasyonlar bağlamında ele alınmıştır. Ancak sosyal medya üzerinden turizm deneyimini paylaşma motivasyonu ile ilişki kalitesi ve sosyal destek arasındaki ilişkiyi doğrudan inceleyen çalışma yapılmamıştır.

Sosyal medya aracılığıyla turizm deneyimi paylaşma motivasyonu üzerinde ilişki kalitesi ve sosyal desteğin etkilerinin belirlenmesi ve ilgili yazında yer alan boşlukların giderilmesi araştırmanın literatüre olan temel katkısı olarak öngörülmektedir. Dolayısıyla bu çalışmanın amacı; sosyal medya aracılığıyla turizm deneyimi paylaşma motivasyonunu etkileyen faktörleri (ilişki kalitesi ve sosyal destek) incelemektir.

2019 Temmuz ve Ağustos aylarında Antalya ilinde turizm deneyimi yaşamış 501 yerli ziyaretçiden Antalya Uluslararası Havalimanı'ndan ayrılışları sırasında, kolayda örnekleme yöntemiyle toplanan verilere analiz yapılmıştır. Araştırma bulguları ilişkisel pazarlama kuramı ve sosyal destek kuramı bakış açısı ile tartışılmış ve yorumlanmıştır. Araştırmanın ilk bölümünde sosyal medyada turizm deneyim paylaşımı ile ilgili literatür taraması yer almaktadır. İkinci bölümde ise literatür desteğiyle oluşturulan 
Alguer \& Çizel (2021), Johti, 3(2), 153-175

hipotezlerin test edildiği yöntem bölümü yer almaktadır. Araştırmanın son bölümünde ise araştırma bulguların tartışıldığ 1 tartışma, teorik ve pratik katkılar, araştırmanın sınırlılıkları ve gelecek araştırmalar için önerilere yer verilmiştir.

\section{KAVRAMSAL ÇERÇEVE}

\subsection{Sosyal Medyada Turizm Deneyimi Paylaşımı}

Sosyal medya, turizm deneyimleri ve paylaşım uygulamalarında psikolojik anlam üretimi ve dolaşımı için yeni kanallar sunmaktadır (Munar \& Ooi, 2012). Bu platformlarda turistler, oluşturdukları içerikleri farklı zaman birimlerinde ve çevrimiçi olarak oluşturabilmekte ve paylaşabilmektedirler (Berger \& Schwartz, 2011). Çünkü sosyal medya araçları "gerçek zamanlı" seyahat deneyimlerinin depolanmasına ve paylaşılmasına imkân sağlamaktadır (Munar \& Jacobsen, 2013). Böylelikle turistler; mesajlaşarak, fotoğraf/video/ses kaydı göndererek, seyahat sitelerinde içerik üreterek ve internet sitelerinde oluşturdukları içerikleri yayınlayarak, deneyimleriyle ilgili gerçek zamanlı paylaşım duygusu kazanmaktadırlar (Munar \& Jacobsen, 2014).

Turistlerin seyahatleri sırasında davranışları ve etkileşime katkıda bulunma istekleri sosyal medyada paylaşımı yapmalarına neden olmaktadır. Bunun en önemli sebeplerinden biri insanların doğuştan gelen "toplumdaki rollerini tanımlama" arzusudur. Bu durum doğal olarak kendini gerçekleştirme arzusuyla ilişkilidir (Maslow, 1943). İnsanlar sosyal medyada paylaşımlarda bulunarak, başkalarının kendileri hakkında düşünmelerini sağlayabilmekte ve böylece kişisel faydalarını arttırabileceklerini düşünmektedirler. Söz konusu bu ben merkezlilik duygusundan kaynaklanan kişilik özelliğinin, turizm sosyal medyasında paylaşımda bulunma davranışıyla ilişkili olduğu bilinmektedir (Munar \& Jacobsen, 2014; Sun vd., 2014).

Sosyal medyada kullanıcılar tarafından paylaşımda bulunma davranışı, bireyin edindiği bilgileri bir ağ içindeki diğer üyelere yayma olarak tanımlanmaktadır (Hsu vd., 2007). Bu nedenle, bireylerin bilgi paylaşımı için davranışlarının kişisel özellikler ve içinde bulundukları ortam tarafından yönlendirilebileceği algısı makul bir şekilde varsayılabilmektedir (Bandura, 1978). Bu noktada özyeterlik ve sonuç beklentileri kişisel faktörlerin yordayıcıları olarak görülmektedir, çünkü her ikisi de kullanıcıların davranışlarını şekillendiren ana etkenler olarak kabul edilmektedir (Bandura, 1978; Bandura, 2006). Kankanhalli vd. (2005) özyeterliliği, bilgi katkısı davranışı üzerindeki etkilerini incelemek için diğer değişkenlerle birleştirmişlerdir. Sonuçlar; insanların sosyal medyada bilgi alışverişi sağladıkları ve özellikle karşı karşıya kaldıkları zor durumlarda başa çıkmaları için öz yeterlilik faktörünün bilgi paylaşımı üzerinde etkisi olduğunu ortaya koymaktadır. Buna dayanarak sonuç beklentileri de kişinin kendi davranışının beklenen sonucunu ifade eder (Bandura, 1978). Sonuç beklentisi, davranış sonucu ortaya çıkacak olan durumdur ve bireylerin sadece kişisel faydalar almayı beklediklerinde bilgilerini paylaşacakları, paylaşımlarda bulunacakları anlaşılmaktadır (Kankanhalli vd., 2005). Ayrıca turistler de sosyal medyada paylaşımlarda bulunarak; bireysel tatmin, kendini gerçekleştirme, insanların kendileri hakkında düşünmelerini isteme, daha fazla tanınmak isteme gibi sosyal ihtiyaçlarını gidermek amacıyla paylaşım davranışları sergilemektedirler (Yoo \& Gretzel, 2008). Dolayısıyla turizm sosyal medyasında paylaşımda bulunanların, gerçek hayatta var olan motivasyonlardan etkilenerek ve birden fazla eğilimden ötürü paylaşımda bulundukları düşünülmektedir (Ma \& Chan, 2014; Yoo \& Gretzel, 2008).

Dünyanın her yerinden internet kullanıcıları sosyal medya ve interneti; fikirlerini, düşüncelerini, deneyimlerini, oluşturdukları içeriklerle; birbirleriyle etkileşimde bulunmak, iletişim kurmak ve paylaşmak amacıyla kullanmaktadır. Turistler de sosyal medya platformlarını seyahat deneyimlerini paylaşmak için baskın bir araç olarak kullanmaktadır (Kim vd., 2013; Styvén \& Foster, 2017). Deneyimler kişiseldir ve insanların belirli turizm destinasyonlarını ve ürünlerini nasıl algılayıp bunlara 
nasıl tepki verdiklerine göre biçimlenmektedirler. Deneyimlerin paylaşılması ise yalnızca tatil özellikleriyle ilgili (örn. bilet fiyatları, hava koşulları ve diğer turistik yerler gibi) değil aynı zamanda bir tatilin kişide bıraktığı nitelikler hakkında, örneğin; fotoğraf paylaşımları, duygular, özyeterlilikler, hayal güçleri ve bireysel faydaları da içerebilmektedir (Baym, 2015; Kim \& Tussyadiah, 2013). Çevrimiçi turizm deneyimlerini paylaşma motivasyonları ise genellikle; özgecilik, kişisel tatmin ve kendini gerçekleştirme ile ilgilidir (Hsu vd., 2007).

Literatürde turistlerin tatilleri ile ilgili deneyimleri veya bir bütün olarak edindikleri bilgileri paylaşmalarının iki tip motivasyondan kaynaklandığı düşünülmektedir. Bunlar; bireysel/benmerkezli motivasyonlar ile toplulukla ilgili/özgecil olan sosyal motivasyonlardır (Hsu vd., 2007; Munar \& Jacobsen, 2014). Sosyal motivasyonlar, turistlerin çevrimiçi deneyimlerinin sanal topluluklar veya diğer sosyal medya kullanıcıları üzerindeki olası etkileriyle ilgilidir (Hsu vd., 2007). Ayrıca toplulukla ilgili olan bu sosyal motivasyonlar fedakârlık barındırırlar ve başkalarının doğru karar verebilmelerine yardımcı olma arzusunu ifade etmektedirler (Ma \& Chan, 2014). Benmerkezli (bencil, ben odakl1) motivasyonların bazıları ise; sosyal etkileşim, güven, kişilik ve karşılıklılık ile sosyal bağların korunması veya arttırılması ile ilgilidir (Baym, 2015; Chang \& Chuang, 2011). Benmerkezli yani kişisel tatmin ve kendini gerçekleştirme olarak bireysel motivasyonlar, insanların başkaları tarafından kendilerinin algılanma biçimidir (Munar \& Jacobsen, 2014).

Günlük hayatın içerisinde sosyal medyanın güçlü konumu nedeniyle çevrimiçi katılımı sağlayan insan davranışı, araştırmacılar tarafından büyük ilgi görmektedir. Çevrimiçi paylaşımlarda bu iki tip motivasyon (bireysel ve sosyal) ise özellikle seyahat deneyimleri konusunda bilgi paylaşımı için değerli faktörler olarak algılanmaktadırlar (Munar \& Jacobsen, 2014). Bu durum, sanal topluluk kültürlerinin değerini arttırmaktadır (Jinyang, 2015).

\subsection{Sosyal Medyada Turizm Deneyim Paylaşımını Etkileyen Faktörler}

\subsubsection{Bireysel Motivasyon}

Sosyal Bilişsel Teoriler (Social Cognitive Theories), sosyal toplumun bir parçası olan insanların bir ortamdaki belirli bir davranışı yapabilmelerinin, kendilerinde söz konusu davranışı gerçekleştirebilme yeteneğine ve kişisel bilişlerine bağlı olduğunu ileri sürmektedir (Bandura, 1978). Bu teorinin araştırma bağlamında bireysel paylaşım eğilimini tetikleyen iki ana bileşeni; özyeterlilik ve sonuç beklentileridir. Sonuç beklentileri, bireyin belirli bir davranışta bulunmasının belirli sonuçlara yol açacağı algısıyla davranması şeklinde tanımlanır (Wilcox vd., 2006). Özyeterlilik ise, toplumsal figür olan bireyin farklı şartlar altında karşılaştığı zorlukları aşması veya üstesinden gelmesiyle kendisinde bir takım yetenek ve üstünlükler olduğuna inanmasıdır (Bandura, 1978). Özyeterlilik ve sonuç beklentileri bireylerin sosyal ilişkiler kurma becerileri açısından ele alındığında bazı araştırmalar özellikle özyeterlilik kavramını; sosyalleşme, utangaçlık, kişiler arası ilişkilerin başlatılması, geliştirilmesi ve sürdürülmesi gibi sosyal ve psikolojik kavramlarla ilişkilendirmişlerdir (Hsu vd., 2007; Major vd., 1995; Özbay vd., 2012; Anderson \& Betz, 2001; Caprara \& Steca, 2005).

Birey davranışları turizm bağlamında ele alındığında bir tatil planı gerçekleştiren turistin seyahati hakkındaki kendi görüş ve önerilerini başka insanlara aktarma duygusuyla ilişkilendirilebilir. Örnek olarak, memnun bir tatil deneyimi yaşamış bireyin başka turistlere deneyimi hakkında bilgiler sunması veya onlarla seyahati sırasında karşılaştığı zorlukları tartışabilmesi, onun sosyal ilişkiler kurabilmesinin yansıması olarak değerlendirebilir (Jacobsen, 2000). Bireysel amaçlar doğrultusunda da olsa turistlerin buna benzer davranışlarda bulunmaları, onların dayanışmacı ve bir topluluğun parçası olarak tanımlanma duygularını arttırmaktadır (Hsu vd., 2007). Genellikle turistlerin toplumsalcılıktan öte bireyselci olarak bilgi paylaşmaları, beklentileri istekleri doğrultusunda gerçekleştiğinde eyleme 
dönüşmektedir (Hsu vd., 2007). Bu noktada özyeterlilik ile sonuç beklentileri arasında anlamlı bir ilişki olduğu öne sürülebilmektedir (Hargittai \& Shafer, 2006).

Sosyal medyada deneyim paylaşma hususunda bireyle ilgili olan yani; benmerkezci davranış paylaşımı beklentileri ve toplumla ilgili beklentiler şeklinde ayrışım bulunmaktadır (Chiu vd., 2006). Baym (2015) ben merkezli motivasyonları; saygı ve tanınma, sosyal bağları arttırma, özsaygıları arttırma, çevrimiçi faaliyetlerden yararlanma ve karşılığında iş birliğini arttırma olanakları olarak açıklamaktadır. Literatürde benmerkezli motivasyonların bazılarının; sosyal etkileşim, güven, kişilik ve karşılıklılık biçimlerinin korunması veya arttırılması ile ilgili olduğu yer almaktadır (Jinyang, 2015). Bu noktada turistlerin bilgi ve deneyim paylaşma isteklilikleri, turizm sosyal medyasında yer alan deneyim paylaşımlarındandır (Munar \& Jacobsen, 2014). Buna karşın, bireylerin görünürde bir fayda sağlamadıkları halde yabancılarla neden bilgi paylaştıkları konusu merak uyandırmaktadır. Bu tür davranışları etkileyen kritik faktörler nelerdir sorusundan hareketle bu paradoksu anlamaya çalışmak için Chang \& Chuang (2011), sosyal motivasyon ve bireysel motivasyonları birleştirerek, sanal bir toplulukta bilgi paylaşım davranışını etkileyen faktörleri araştırma çalışması gerçekleştirmişlerdir. Çalışmada bireysel motivasyonun bilgi paylaşım davranışı üzerindeki düzenleyici etkileri analiz edilerek karşılıklılığın ve kişilik yapısının bilgi paylaşımı üzerinde önemli ve olumlu bir etkisi olduğu bulunmuştur (Jinyang, 2015; Chang \& Chuang, 2011).

Turistler sosyal medyada, kendileri için veya başkaları için yararlı buldukları konularda veya sosyal bağlantılarını sürdürmek amacıyla paylaşımda bulunmaktadırlar (Munar \& Jacobsen, 2014). Dolayısıyla turistlerin, sosyal medyada yer alan içeriklere duydukları güven sayesinde bu tür bireysel ve sosyal motivasyonlar etkisiyle paylaşımda bulundukları düşünülmektedir. Bireysel veya sosyal motivasyonla paylaşımda bulunan bir kişi, kendisinde güven algısına sahip olduğunu göstermektedir (Hsu \& Lin, 2008). Böylece ilişki kalitesinin güven unsurunun, paylaşım motivasyonunu (bireysel/sosyal) etkilemesi muhtemel görülmektedir. Çevrimiçi platformlarda deneyim alışverişinde bulunan insanların ilişkilerinde bağlılık etkili bir kavramdır ve ilişkisel işlemleri sürdürmenin kilit noktası olarak kabul edilmektedir (Jaiswal vd., 2010). Dolayısıyla turizm deneyimi paylaşılmasında, deneyimi paylaşan ve karşıda bulunan kişi arasında ilişki bağlılığı kurulmaktadır.

Özellikle sosyal motivasyonlar fedakârlık ve özgecilik tutumları içerdiğinden bağlılık; başarılı, dostane ve uzun vadeli ilişki kurmanın da anahtarı sayılmaktadır (Morgan \& Hunt, 1994). Böylece ilişki kalitesinin bağl1lık unsurunun da paylaşım motivasyonunu etkilemesi muhtemeldir. Turistler internet üzerinden deneyimlerini paylaşırken izlenimlerini de paylaşmaktadırlar, bu paylaşım bireysel motivasyondan kaynaklanmaktadır (Munar \& Jacobsen, 2014). Ayrıca turistler deneyimlerini paylaşarak turistik ürün ve hizmetler hakkında başka insanlara yardımcı olduklarını düşünmektedirler, bu paylaşım eylemi de sosyal motivasyondan kaynaklanmaktadır (Munar \& Jacobsen, 2014). Sosyal ilişkilerde tüm bu paylaşımlar ancak memnuniyetin varlığında gerçekleşebilirler (Gustafsson vd., 2005). Bu nedenle ilişki memnuniyeti algısına sahip turistler bu motivasyonlarla deneyimlerini başkalarıyla paylaşmaktadırlar, dolayısıyla memnuniyetin turistlerin paylaşım motivasyonunu etkilemesi varsayılabilmektedir. Yukarıda verilen bilgiler doğrultusunda aşağıdaki hipotez geliştirilmiştir:

Hipotez 1: İlişki kalitesi, sosyal medya aracılığıyla turizm deneyimi paylaşma motivasyonu ile pozitif ilişkilidir.

\subsubsection{Sosyal Motivasyon}

İktisat biliminde, tek insanın ekonomisinde yalnız bireyin sosyolojisi olamayacağı görüşü hâkimdir (Eralp, 1983). Dolayısıyla bir grup insandan minimum iki insana kadar kişiler arası ilişkilerde sosyal ăg kavramı önemli bir rol oynamaktadır (Stanley \& Faust, 1994). Çevrimiçi bir topluluğun üyeleri de bilgi 
paylaşımıyla bağlı oldukları topluluğa katkıda bulunarak, bireysel eylemler gerçekleştirirler (Bagozzi \& Dholakia, 2002). İş bu insanların elde ettikleri bilgileri başkalarıyla paylaşmaları, onların özgecil (yardımsever) bir eylemde bulunmalarının yansımalarıdır (Baym, 2015). Sosyal motivasyonlar (toplulukla ilgili) da kişilerarası ilişkilerde; sosyal medyaya katılım, güven, sosyal sermaye ve saygınlık içermektedirler (Baş, 2018). Günlük hayattaki toplulukların sosyal medyadaki yansıması olan bu sanal topluluklar; bireylerin sahip oldukları değerlerden, toplumsal normlarından, toplumu ilgilendiren fikirleri ve anlayışları ile ilgili paylaşımlarından meydana gelmektedir. Sanal toplulukları oluşturan kişiler turist iseler bu kimlik ile anıldıklarında, kendilerini rutin hayat çizgisinden farklı bir konumda algılamakta ve topluluk içerisindeki faaliyetleri ile hem bireysel hem de toplumsal bir şekilde vazifelendirilmiş gibi hissetmektedirler (Gretzel \& Yoo, 2008). Bu tarz duygulara sahip olan turistlerin, seyahat sitelerindeki insanlara veya diğer inceleme sitelerine, talep ve görüşlerini sürekli bildirmekle yükümlüymüş gibi hissettikleri düşünülmektedir (Gretzel \& Yoo, 2008).

Turistler paylaşım davranışlarında bulunurken özgecil eğilimlerde olsalar da itibarlarını arttırma veya özyeterlik duygularını arttırma gibi bireysel faydaları da hedefliyor olabilmektedirler. Buna rağmen kendileri için yararlı olan bir siteye katkıda bulunmak gibi benmerkezci bir nedenin toplulukla ilgili bir boyutu da bulunabilir. Çünkü Sigmund Freud'a (Sigmund, 2017) göre, topluluğu oluşturan bireyler bazı zamanlar kendilerinde rastlanmayan özelliklere sahip olmaktadırlar. Dolayısıyla kalabalık bir ortamda yaşanmasından ötürü bireyin kitle içerisinde karşı konulmaz bir güce ve yetiye sahip olma duygusuna kapılması ve böyle bir duyguyla kendini içgüdüsel isteklerine teslim etmesi doğal bir sonuçtur. Çevrimiçi sosyal ağlar bağlamında, insanların özgecil davranışlarla kendileri için önemli olan kişi ve gruplarla iletişim halinde olmaları, onlarla deneyimlerini paylaşmaları ve onlara yardım etmek için sosyal medyayı kullanmaya daha istekli olmaları bu durumundan kaynaklanmaktadır (Ma \& Chan, 2014).

Sosyal bir varlık olan insanın sonuç beklentileri, onun sosyal ilişkiler kurma becerilerini tanımlarken, özyeterlilik kavramı ise; sosyalleşme, kişilerarası ilişkilerin başlatılması, geliştirilmesi ve sürdürülmesi gibi sosyal ve psikolojik kavramlarla ilişkilendirilmiştir (Hsu vd., 2007; Özbay vd., 2012; Anderson \& Betz, 2001; Caprara \& Steca, 2005). Bu noktada, turistler deneyim paylaşımlarıyla çevrimiçi ağlarda daha fazla tanınmak isteyebilir ve başka turistlere yardımcı olabilecekleri inancı geliştirebilirler, bunlar turistin sonuç beklentilerine sahip olduğunu göstermektedir. Turistler deneyimlerini sosyal ağlarında paylaştıklarında, kendi kendilerine yetebildiklerini yani özyeterliliklerinin var olduğunu da sergilemektedirler. Tüm bu paylaşım davranışlarını bireysel motivasyonla gerçekleştirmektedirler (Munar \& Jacobsen, 2014). Bu noktada, turistlerin ürettikleri içerikler aracılığıyla duygusal destek sağladıkları düşünülmektedir. Böylelikle duygusal desteğin, deneyim paylaşım motivasyonu üzerinde etkisi olduğu argümanı ileri sürülebilmektedir.

Sosyal destek, bir bireye sıcaklık ve anlayış getirebildiğinden, kişinin psikolojik ihtiyaçlarını karşılama yanıtı olarak da değerlendirilebilir (Obst \& Stafurik, 2010). Bu tür destek, bir tür hevesli geri bildirim olarak, destek ihtiyacı hisseden kişinin sorununu çözmek için doğrudan yardım sağlanamasa bile kişinin kendisini daha iyi hissetmesine yardımcı olabilmektedir (Obst \& Stafurik, 2010). Turizm deneyimi paylaşma motivasyonu olan sosyal motivasyonla karşılaki kişilere tam anlamıyla yardım sağlanamasa da diğerkâmlık duygusuyla onlara yardımcı olmak amaçlanmaktadır. Bu nedenle sosyal desteğin, sosyal motivasyonla deneyim paylaşımı ile ilişkili olduğu düşünülmektedir.

Çevrimiçi kurulan bir ilişkide sosyal desteğin toplum duygusu ile olumlu ilişkili olduğu ortaya koyulmuştur (Oh vd., 2014). Bu tür bir algıya sahip olan kullanıcı, bilgilerini başkalarıyla paylaşmak veya yardımlaşmak isteyecektir (Liang vd., 2011). Bu noktada yine sosyal desteğin, turistlerin paylaşımlarında yer alan bu toplum duygusundan kaynaklanan fedakârlık (özgeci) motivasyonları ile 
ilişkili olduğu varsayılabilmektedir. Çevrimiçi ağlar üyelerine, nesnelerin (fotoğraf, video vb. gönderiler gibi) kaç kez işaretlendiğini söyleyen "sosyal paylaşım imleci ikonları" olarak adlandırılan "beğen", "paylaş" ve "takip et" butonları gibi kalite çıkarım işlevlerini içermektedirler (Chen vd., 2011; Hajli, 2014). Bu ikonlar, bilgilendirici ve duygusal destek sağlamaktadırlar (Gerlitz \& Helmond, 2013). Destek almanın insanları psikolojik olarak iyi etkilediği düşünüldüğünde bu çeşit iyi deneyimler, insanları destekçileriyle olan etkileşimlerinde tatmin etmekte ve sosyal ihtiyaçlarını karşılamaları konusunda onlara yardımcı olabilmektedir. Bu nedenle, sosyal desteği iyi olan bir toplulukta, insanlar genellikle yardım alışverişi için başkalarıyla etkileşime girmektedirler (Laurenceau vd., 1998). Örneğin bir turistin, sosyal ağında ne kadar çok arkadaşı varsa (yani geniş bir topluluk), zorluklarla veya sorunlarla karşılaştığı zaman güvenebileceği, yardım isteyebileceği kişileri bu arkadaşları arasından kolayca bulabilmesi sosyal desteğin varlığına işaret eder (Luo \& Zhong, 2015). Çünkü sosyal medyada arkadaşlarından destek aldığını hisseden turist, bir ürün veya hizmet hakkında karşılaşacağı zorluğu sosyal motivasyon bağlamında karşılıklı yardımlar ile aşabilecektir. Bu hususta sosyal destek kaynakları olan bilgi desteği ve duygusal destek, turistlerin sosyal medya üzerinden deneyim paylaşım motivasyonu olan sosyal motivasyonla ilişkilidir denilebilir.

Sosyal destek kavramı, sosyal destek teorisinden türetilmiştir (Shumaker \& Brownell, 2010). Sosyal destek teorisi ise sosyal ilişkilerde biliş, duygu ve davranışların nasıl etkilendiğini açıklamak için önerilmiştir (Lakey \& Cohen, 2000). Bu teori, destekleyici davranışın insanların karşılaştıkları olumsuz konularda onların korunması ve onlara katkıda bulunulmasını ileri sürmektedir (Lakey \& Cohen, 2000; Maier vd., 2015). İnternet üzerindeki etkileşimler sanal olduğundan ve metinsel kaynak içerdiğinden, sosyal medya kullanıcıları için çevrimiçi sosyal destek; bilgi desteği ve duygusal destek olmak üzere ikiye ayrılmaktadır (Coulson, 2005). Bilgi desteği, karşıdaki kişinin problemlerini çözmesine yardımcı olabilecek bilgileri ve tavsiyeleri sağlamayı ifade etmekte ve çözümler, planlar veya yorumlar sağlayabilmektedir (Liang vd., 2011). Duygusal destek, başka bir kişiye bakım, sempati ve anlayış gibi duygusal desteklerin sağlanmasından oluşmaktadır (Taylor vd., 2004). Dolayısıyla duygusal destek, bireylerin endişelerini ifade etmeye odaklanır ve dolaylı olarak sorunların çözülmesine yardımcı olabilmektedir (Taylor vd., 2004).

Turistler için sosyal destek, diğer turistlerden (Huang \& Hsu, 2009) veya turistin arkadaşları ile ailesi gibi yakın bağlarından sağlanabilmektedir (Kim \& Tussyadiah, 2013). Her gün çok sayıda turist, yakın zamanda ziyaret ettikleri yerlerin fotoğraflarını ve videolarını paylaşmaktadır (Huang vd., 2019). Turistler bu paylaşımlarını bireysel motivasyonla (benmerkezli) yapabildikleri gibi sosyal motivasyonla (özgeci) da yapabilmektedirler (Munar \& Jacobsen, 2014). Turistler çevrimiçi ağlarında deneyimlerini paylaşarak başka kullanıcılarla destek alışverişinde bulunmayı onaylarlar. Örneğin sosyal medya uygulamaları "beğen, paylaş, takip et ve abone ol" gibi kalite çıkarım işlevlerini içerir, bunlar bilgilendirici ve duygusal destek sağlarlar (Gerlitz \& Helmond, 2013). Sosyal ağ grubundaki akranlarına veya akrabalarına paylaşımda bulunan bir turist de bu kalite çıkarım işlevlerine maruz kalabilir ve sosyal destek algısıyla paylaşımlarını buna göre şekillendirebilir. Verilen bilgiler doğrultusunda aşağıdaki hipotez geliştirilmiştir:

Hipotez 2: Sosyal destek, sosyal medya aracılığıyla turizm deneyimi paylaşma motivasyonu ile pozitif ilişkilidir.

\subsection{3. İlişki Kalitesi ve Sosyal Destek İlişkisi}

Morgan ve Hunt'a (1994) göre: "İlişkisel pazarlama, başarılı ilişkiler kurmaya, geliştirmeye ve sürdürmeye yönelik tüm pazarlama faaliyetleri"ni ifade etmektedir. İlişkisel pazarlama kuramının amacı, yeni tüketiciler kazanmayı, mevcut tüketiciyi elde tutmayı ve tüketici bağlılığını sağlamayı amaç edinmektedir (Berry, 1983). Teoriye göre ilişki kalitesi, anahtar bir kavramdır (Palmatier vd., 2006). 
Araştırmalar ilişki kalitesinin esas olarak üç yönü olduğunu göstermektedir; güven, ilişki memnuniyeti ve ilişki bağl1lı̆̆1 (Wulf vd., 2001; Garbarino \& Johnson, 1999). Rotter (1967)'a göre güven; birinin güvendiği bir değişim ortağına güvenmek için istekli olmasıdır. Ayrıca bir bireyin bir başkasının sözüne güvenebileceği, birey tarafından gösterilen genel bir beklenti olduğu görüşüne dayanmaktadır. Morgan ve Hunt'a (1994)göre bağl1lık; ilişkilerinin önemine inanan ve bunu sürdürmek için ellerinden geleni yapmaya istekli olan kişilerin ortaklıkları demektir. Başka bir deyişle, bağlılığı bulunan taraf, ilişkiyi sürdürmeye değer görmekte ve onu sonsuza dek korumayı garanti etmektedir. Memnuniyet ise insanların diğer insanlarla olan ilişkilerini değerlendirmeleri sonucu gelişen, olumlu duygusal durumlarını ifade etmektedir. Birden fazla çalışmada, bağl1lık ve güven ile bağlılık ve memnuniyet, ilişki kalitesinin tutarlı yapıları olarak ele alınmıştır (Morgan \& Hunt, 1994; Moorman vd., 1993; Garbarino \& Johnson, 1999; Gustaffsson vd., 2005).

Turistler için ilişki kalitesi, herhangi bir turistik ürün/hizmet hakkında deneyim yaşayanların, birbirleriyle etkileşime girerek bu deneyimlerini ilişki kalitesi unsurlarıyla (güven, bağlılık ve memnuniyet) sosyal medyada paylaşmalarıdır. Turistlerin özellikle yardımseverlik duygularıyla içeriklerini paylaşırken sosyal ağ grubundaki insanlara güven duymaları gerekir. Çünkü ilişkisel güven, sosyal ilişkilerde kişilerin birbirlerine itimat etmelerini sağlayan bir kavramdır (Morgan \& Hunt, 1994). Turistler deneyimlerini paylaşırken etkileşimde oldukları insanlarla dostane ve uzun bir ilişki kurmak isterler, bu nedenle ilişkisel bağlılık onların paylaşımlarında yer almaktadır. Son noktada turistlerin başkaları için deneyimlerini paylaşmaları, onlarda sosyal ilişkiler için gerekli olan güven ve bağlılık unsurlarının yanı sıra ilişkisel memnuniyeti de gerektirmektedir. Dolayısıyla sosyal etkileşim için gerekli olduğu gibi sosyal medyada turizm deneyimi paylaşırken de ilişki kalitesi değerli bir kavramdır (Gustaffsson vd., 2005; Lai \& Chen, 2014; Pan vd., 2007).

Sosyal medyaya ilişkin duygusal destek; önemseme, anlama ve empati gibi duygusal kaygıları içeren mesajları sağlamak anlamına gelirken, bilgilendirme desteği; sorunların çözümünde yardımcı olabilecek öneriler, tavsiyeler ve bilgiler biçiminde mesajlar verilmesi anlamına gelmektedir (Taylor vd., 2004; Liang vd., 2011). Çevrimiçi sosyal ağlar, kullanıcılara sosyal değerler sunmaktadır, onların başkaları ile yakın ilişkiler kurmasını ve refahlarını arttırmalarını sağlamak için güçlü bir araç konumundadır (Obst \& Stafurik, 2010). Çevrimiçi ağlarda üretilen bilgisel ve duygusal desteklerin tüketicilerdeki güven, bağlılık ve memnuniyeti arttırması muhtemel görülmektedir (Hajli, 2014). Kullanıcıların çevrimiçi ağlara katılımı, bağlılık üzerinde olumlu bir etkiye sahiptir, bu da onların çevrimiçi ağlarda üretilen içeriklere daha fazla güvenebilmelerini sağlamaktadır (Casaló vd., 2008). Ayrıca sanal bir mecraya duyulan güvenin, kullanıcıların bu sanal platformlara katılımı üzerinde de olumlu katkıları olduğu bilinmektedir (Casaló vd., 2008). Bilgisel destek ve duygusal destek üzerinde, çevrimiçi sosyal ağlara güvenme düşüncesi; topluluklar, forumlar ve yorum siteleri gibi sosyal medya mekanizmalarında arama yapan kullanıcıların güven ve memnuniyet algılarını artırdığını göstermektedir (Hajli, 2014). Güven ve memnuniyetin bulunduğu bir ilişki, arkasında bağlılı̆̆ı da meydana getirmektedir (Morgan \& Hunt, 1994). Böylelikle sosyal medyada yer alan içeriklerden bilgisel ve duygusal destek alan kullanıcıların, bu üç ilişki kalitesi unsuruyla karşılaşmaları doğal olacaktır (Liang vd., 2011).

Sosyal değişim kuramı, bireylerin başka bireylere yarar sağladıklarında kendileri de zor bir durumda kaldıkları zaman diğer insanlardan aynı karşılığın geleceği düşüncesiyle hareket ettiklerine dayanmaktadır (Jinyang, 2015). Bu noktada, bir kullanıcı sosyal ă̆ sitesindeki arkadaşlarından destek alırsa, benzer bir iyilik iade etmek durumunda kalabilir. Sosyal destek algısından kaynaklanan bu davranışsal etken kişiyi karşılıklı güven, memnuniyet ve bağlılığa yani ilişki kalitesi unsurlarına teşvik etmektedir (Crocker \& Canevello, 2008; Liang vd., 2011). Sonuç olarak sosyal etkileşimler ve deneyim paylaşımı bağlamında bu karşılıklı ilişkiler, sosyal desteğin ilişki kalitesi üzerinde etkisi olduğunu 
düşündürmektedir. Önceki çalışmalarda onaylandığı gibi sosyal desteğin, ilişki kalitesi üzerindeki olumlu etkileri (Hajli vd., 2017; Liang vd., 2011) bu araştırma kapsamında tekrar varsayımsal olarak ilişkilendirilmektedir. Bunların ışığında aşağıdaki hipotez geliştirilmiştir:

Hipotez 3: Sosyal destek, ilişki kalitesi ile pozitif ilişkilidir.

Literatür desteği ile geliştirilen hipotezler Şekil 1'de görülen ilişki modeli ile test edilmiştir. Modelde, sosyal medya ile turizm deneyimi paylaşma motivasyonunun öncülleri olarak sosyal destek ve ilişki kalitesi kullanılmıştır. Sosyal destek bilgi desteği ve duygusal destek olarak iki boyuttan oluşurken, ilişki kalitesi ise güven, bağlılık ve memnuniyet boyutlarından oluşmaktadır. Hipotezler yapısal eşitlik modeli ile test edilmiştir.

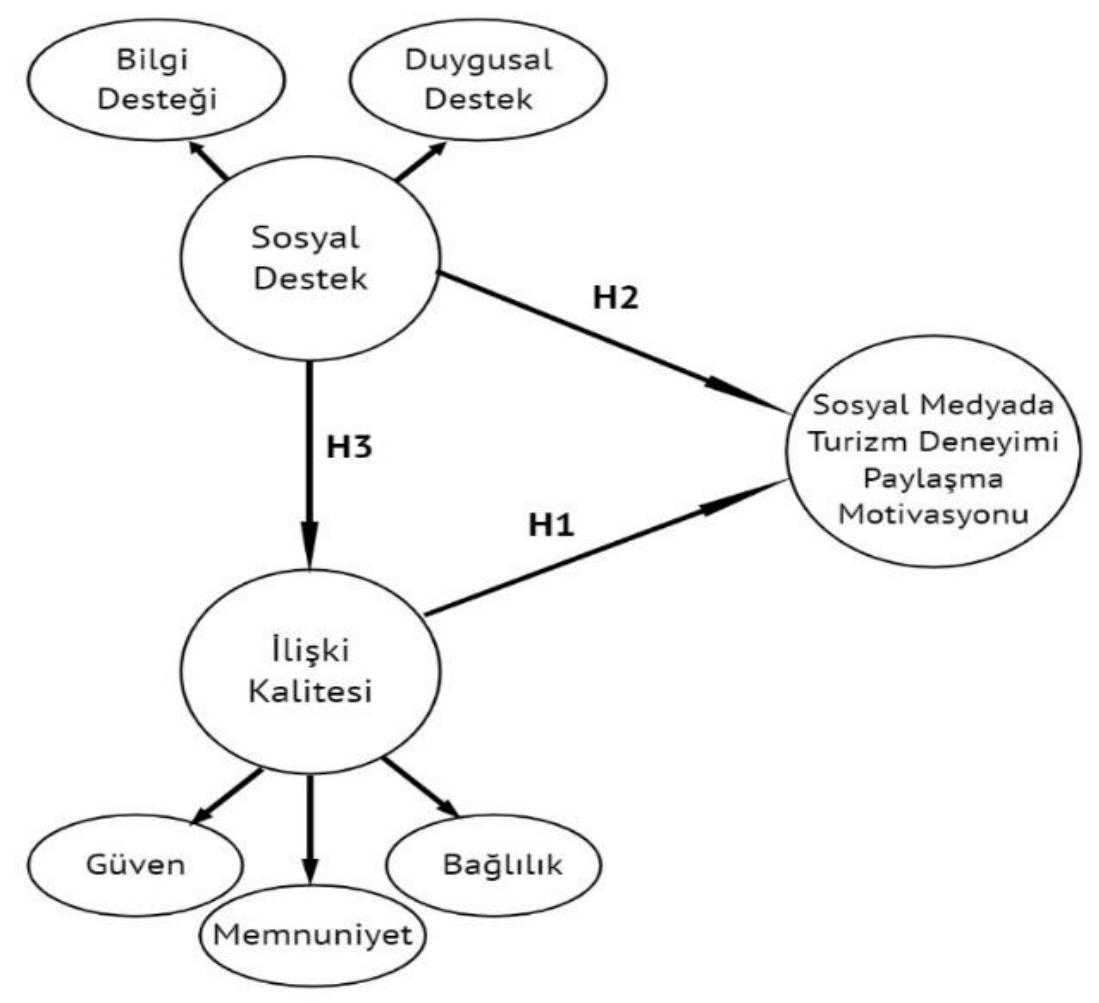

Şekil 1. Teorik model

\section{YÖNTEM}

\subsection{Veri Toplama Aracı}

Araştırma verileri hazırlanan anket formu ile yüz yüze görüşülerek toplanmıştır. Anket uygulaması için Haziran 2019'da ilgili yerlerden gerekli izinler ile Uluslararası Antalya Havalimanı (AYT)'daki güvenlik önlemleri nedeniyle ek izinler alınmış ve veri toplama işlemi gerçekleştirilmiştir. Uluslararası Antalya İç Hatlar Terminali (Domestic Terminal)'nde iç hat uçuşlarına izin veren tüm kapılarda, dönüş yolcusu olanlardan potansiyel katılımcılar belirlenerek, gönüllülük esasına dayalı anket dağıtım ve toplama işlemi gerçekleştirilmiştir. Anket formu iki bölümden oluşmaktadır. Birinci bölümde araştırmanın değişkenlerini ölçmek için kullanılan ölçüm araçları yer almaktadır. Sosyal medya aracılığıyla turizm deneyimi paylaşma motivasyonunu ölçmek üzere Munar ve Jacobsen'in (2014) ölçeği kullanılmıştır. Bu ölçek 6 ifadeden oluşmaktadır. Sosyal destek ve ilişki kalitesini ölçmek üzere Liang, Ho, Li ve Turban'ın (2011)'nin geliştirdikleri 16 ifadeden oluşan ölçek kullanılmıştır. Ölçüm aracında 7'li Likert tipi (1-kesinlikle katılmıyorum ile 7-kesinlikle katıllyorum şeklinde bir uçtan diğerine değişen) ölçek kullanılmıştır. Anket formunun ikinci bölümünde ise katılımcıların özelliklerini 
belirlemeye yönelik (sosyal medya türleri, seyahat sitelerini kullanım sıklığı, kullanım süresi, kullanım şekli ve demografik sorular) yer almaktadır.

Araştırma verileri, 2019 yılı Temmuz ve Ağustos ayları içerisinde Antalya'yı ziyaret eden yerli turistlerden, Antalya Uluslararası Havalimanı'ndan ayrılışları sırasında toplanmıştır. Araştırmada üç ayrı çalışma grubu kullanılmıştır; birinci (265 katılımcı verileri) ve ikinci (301 katılımcı verileri) çalışma grubu ile ölçeğin Türkçe'ye uyarlama çalışması yapılmış, son grupta toplanan veriler (501 katılımcı verileri) ile araştırma hipotezleri test edilmiştir.

\section{2. Ölçeğin Geçerlilik Güvenilirlik Testleri}

Ölçüm aracı uyarlama sürecinde açımlayıcı ve doğrulayıcı faktör analizi kullanılmıştır (Jöreskog \& Sörbom, 1998). İlk aşamada toplanan veriler $(n=265)$ üzerinden öngörülen faktör yapısı açımlayıc1 faktör analiziyle (AFA) analiz edilmiştir. Sonraki aşamada ise ölçeğin faktör yapısı ikinci çalışma grubu ile $(n=311)$ doğrulayıcı faktör analizi (DFA) ile analiz edilmiştir.

Tablo 1. Ölçek ifadeleri ve faktör yük değerleri

\begin{tabular}{|c|c|}
\hline$n=265$ & $\begin{array}{l}\text { Faktör } \\
\text { yükleri }\end{array}$ \\
\hline \multicolumn{2}{|l|}{ Sosyal Destek (SD) } \\
\hline Zorluklarla karşılaştığımda, en sevdiğim sosyal paylaşım sitemdeki bazı insanlar yanımdadırlar. & ,76 \\
\hline Zorluklarla karşılaştı̆̆ımda, favori sosyal paylaşım sitemdeki bazı insanlar beni rahatlatırlar. & ,79 \\
\hline $\begin{array}{l}\text { Zorluklarla karşılaştığımda, en sevdiğim sosyal paylaşım sitemdeki bazı insanlar ile özel duygularımı } \\
\text { paylaşabiliyorum. }\end{array}$ & ,68 \\
\hline $\begin{array}{l}\text { Zorluklarla karşılaştığımda, en sevdiğim sosyal paylaşım sitemdeki bazı insanlar benim iyiliğim için } \\
\text { uğraşıyorlar. }\end{array}$ & ,77 \\
\hline Favori sosyal paylaşım sitemde, bazı insanlar yardıma ihtiyacım olduğunda önerilerde bulunurlar. &, 81 \\
\hline $\begin{array}{l}\text { Bir sorunla karşılaştığımda, favori sosyal paylaşım sitemdeki bazı insanlar sorunu aşmama yardımcı } \\
\text { olacak bilgiler verirler. }\end{array}$ & ,77 \\
\hline \multicolumn{2}{|l|}{$\begin{array}{l}\text { Zorluklarla karşılaştığımda, favori sosyal paylaşım sitemdeki bazı insanlar zorluğun nedenini } \\
\text { keşfetmemde önerilerde bulunarak yardımcı olurlar. }\end{array}$} \\
\hline \multicolumn{2}{|l|}{ İlişki Kalitesi (İK) } \\
\hline Favori sosyal paylaşım siteme üye olmaktan gurur duyuyorum. & ,79 \\
\hline Favori sosyal paylaşım siteme ait olduğumu hissediyorum. & ,76 \\
\hline Favori sosyal paylaşım sitemin uzun vadeli başarısını önemsiyorum. & 70 \\
\hline Favori sosyal paylaşım sitemi kullanmaktan tatmin oluyorum & 80 \\
\hline Favori sosyal paylaşım sitemi kullanmaktan memnunum. & 80 \\
\hline \multicolumn{2}{|l|}{ Tablo 1'in Devamı } \\
\hline Favori sosyal paylaşım sitemi kullanmaktan mutluyum. & ,84 \\
\hline Favori sosyal paylaşım sitemin performansı her zaman beklentilerimi karşılıyor. & ,73 \\
\hline En sevdiğim sosyal paylaşım sitesi, iyi bir sosyal paylaşım sitesi olarak sayılabilir. & 77 \\
\hline Favori sosyal paylaşım sitem, güvenilir bir sosyal ağ sitesidir. & 64 \\
\hline \multicolumn{2}{|l|}{ Paylaşma Motivasyonu (PM) } \\
\hline Turizm deneyimlerimi paylaşarak, başkalarına yardım etmek istiyorum. &, 80 \\
\hline Turizm deneyimlerimi paylaşarak, insanların kötü ürünler kullanmasını önlemek istiyorum. &, 80 \\
\hline Turizm deneyimlerimi paylaşarak, benim için yararlı olan web sitelerine katkıda bulunmak istiyorum. & 86 \\
\hline Turizm deneyimlerimi paylaşarak, sosyal bağlantıları ve dostluğu korumak istiyorum. & ,76 \\
\hline Turizm deneyimlerimi paylaşarak, izlenimlerimi internet üzerinden paylaşmayı seviyorum. & ,76 \\
\hline Turizm deneyimlerimi paylaşarak, deneyimlerim için daha fazla tanınmak istiyorum. & 63 \\
\hline
\end{tabular}

Ölçüm aracı ile ilgili açımlayıcı faktör analizi sonuçları Tablo 1'de verilmiştir. Değişkenlere ait ifadelerin faktör yükleri 0,63 ve 0,86 arasında değişmektedir. Araştırma grubunun faktör analizine 
uygunluğunu ortaya koymak için Kaiser-Mayer-Olkin (KMO) değeri hesaplanmıştır. 0,926 olan KMO değeri yeterli düzeydedir (Büyüköztürk, 2011). Dağılımın normallik düzeyinin faktör analizinin koşularını karşılama durumu Bartlett testi ile incelenmiş (Kline, 1993) ve 4624,787 olarak hesaplanmıştır. Elde edilen bu değerin 0,000 düzeyinde istatistikî olarak anlamlı olduğu görülmüştür. Faktör analizi sonucu elde edilen 3 faktörün toplam varyansı açıklama oranı da \%68,16 düzeylerinde gerçekleşmiştir (Tablo 1).

İkinci aşamada yapı geçerliliği testi için doğrulayıcı faktör analizi kullanılmıştır. Bu aşamada öncelikle güvenilirlik (yapı güvenilirliği, madde güvenilirliği, açıklanan ortalama varyans) analizleri yapılmıştır (Fornell \& Larcker, 1981). Değerlerin hepsi önerilen 0.50' değerinden yüksektir ve ölçüm aracının güvenilir olduğunun göstergesidir (Fornell \& Larcker, 1981) (Tablo 2). Bunlara ilave olarak, ölçüm aracında yer alan tüm alt ölçeklerin (sosyal destek: 0.92, ilişki kalitesi: 0.94, paylaşım motivasyonu: 0.90 ve ölçeğin tamamının 0.95) Cronbach alfa değeri 0.70'in üzerindedir. Bu değerlere göre ölçeğin iç tutarlılık açısından oldukça iyi bir düzeyde olduğu söylenebilir (Nunnally \& Bernstein, 1994). Madde güvenilirliği, yapı güvenilirliği ve açıklanan ortalama varyans ise Tablo 2'de verilmiştir.

Açımlayıcı faktör analizi sonucunda elde edilen 3 faktör ve 22 ifade Lisrel programı kullanılarak doğrulayıcı faktör analizi ile test edilmiştir. Doğrulayıcı faktör analizi çıktıları Tablo 2'de gösterilmiştir.

Tablo 2. Ölçüm modeli için istatistiksel değerler $(n=311)$

\begin{tabular}{|c|c|c|c|c|c|c|c|c|}
\hline & \multicolumn{3}{|c|}{ Korelasyonlar } & \multirow{2}{*}{$\lambda$} & \multirow{2}{*}{ t values } & \multirow{2}{*}{$\alpha$} & \multirow{2}{*}{ CR } & \multirow{2}{*}{ AVE } \\
\hline & SD & İK & $\mathbf{P M}$ & & & & & \\
\hline Sosyal Destek (SD) & 1 & $\mathbf{0 , 5 9}$ & 0,44 & & & ,92 & ,92 & ,62 \\
\hline SD1 & & & & ,70 & 13,57 & & & \\
\hline SD2 & & & & ,77 & 15,56 & & & \\
\hline SD3 & & & & ,70 & 13,77 & & & \\
\hline SD4 & & & &, 82 & 17,07 & & & \\
\hline SD5 & & & &, 88 & 19,23 & & & \\
\hline SD6 & & & &, 80 & 16,54 & & & \\
\hline SD7 & & & &, 83 & 17,62 & & & \\
\hline İlişki Kalitesi (İK) & & 1 & $\mathbf{0 , 5 4}$ & & & ,94 & ,94 & ,63 \\
\hline İK1 & & & &, 82 & 17,29 & & & \\
\hline İK2 & & & & ,79 & 16,36 & & & \\
\hline İK3 & & & &, 80 & 16,60 & & & \\
\hline İK4 & & & &, 86 & 18,64 & & & \\
\hline İK5 & & & &, 81 & 17,02 & & & \\
\hline İK6 & & & &, 86 & 18,70 & & & \\
\hline İK7 & & & & ,76 & 15,48 & & & \\
\hline İK8 & & & &, 77 & 15,77 & & & \\
\hline İK9 & & & & 67 & 13,11 & & & \\
\hline Paylaşma Motivasyonu (PM) & & & 1 & & & ,90 &, 89 &, 58 \\
\hline PM1 & & & & ,71 & 13,68 & & & \\
\hline PM2 & & & &, 73 & 14,31 & & & \\
\hline PM3 & & & &, 79 & 15,99 & & & \\
\hline PM4 & & & &, 83 & 17,28 & & & \\
\hline PM5 & & & &, 81 & 16,55 & & & \\
\hline PM6 & 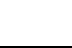 & 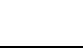 & & ,68 & 12,81 & & & \\
\hline
\end{tabular}


Araştırmaya ait uyum indekslerinin oldukça iyi oldukları görülmektedir (Hair, Black, Babin, \& Anderson, 2014). Tablo 2 incelendiğinde, $x^{2} / d f$ ve RMSEA ve bütün uyum iyiliği ölçütlerinin mükemmel uyum (CFI, NFI, AGFI, SRMR, GFI) gösterdikleri belirlenmiştir (Schermelleh-Engel, Moosbrugger, \& Müller, 2003). Yani her bir değişkenin kendisini oluşturan ifadeleri-maddeleri doğru bir biçimde temsil ettiği (yapı geçerliliği) doğrulanmıştır. Tablo 2'de ölçüm modeline ait parametre tahminleri ve hesaplanan $t$ değerleri derecesinde anlamlı bulunmuştur (Bagozzi \& Dholakia, 2002).

Yakınsama geçerliliği testi açıklanan ortalama varyans (AVE) değeri hesaplanmıştır (Fornell \& Larcker 1981). Tüm değerler ilgili yazında istenen değeri (AVE> 0,05) karşılamaktadır (Bagozzi \& Dholakia, 2002; Fornell \& Larcker, 1981; Kline, 1993). Ayrıca tablo 2'de yer alan korelasyon değerleri de yakınsama geçerliliğinin kanıtı olarak görülebilir. Ayrışma geçerliliğinin kontrolü için yine Fornell ve Larcker (1981)'in önerdiği yöntem kullanılmıştır. Bu yönteme göre bir yapıya ait ortalama açılanan varyans o yapının diğer yapılarla arasındaki korelasyon katsayısının karesinden büyük olmalıdır. Bu yönteme göre değişkenler arası ayrışma geçerliliğinden sağlandığı görülmektedir.

\subsection{Ortak Yöntem Yanlılığı}

Ortak yöntem yanlılığı, varyansın ölçme araçlarının ölçmeye çalıştıkları yapılardan çok ölçme yöntemine dayanması demektir (Podsakoff vd., 2003). Tüm değişkenlerin tek bir anketle ölçüldüğü, farklı değişkenlere özgü değerlendirmelerin aynı kişi tarafından ve benzer zaman dilimleri içerisinde yapıldığı çalışmalarda, ortak yöntem varyansı hataları ortaya çıkmaktadır (Malhotra vd., 2004). Bu nedenle ortak yöntem yanlılığı şüphesini yok saymak üzere Podsakoff vd. (2003) model ve veri toplama süreçlerinde yapısal prosedürlerin kullanılmasını önermektedirler. $\mathrm{Bu}$ araştırmada araştırmacı anonimliği korunmuş, bağımsız ve bağımlı değişkenler anket formunda ayrılmıştır (Podsakoff vd., 2003). Analiz kısmında ortak yöntem yanlılığının etkisi Harman'ın tek faktör testi ile istatistiksel olarak değerlendirilmiştir. Yapılan analiz sonucunda değişkenlerin tek faktör altında bir araya gelişlerinde açıklanan toplam varyans oranının sınır değer olan \%50'nin altında olduğu tespit edilmiştir (34,487\%) (Podsakoff \& Organ, 1986). Sonuç olarak, varyans yüzdesinden dolayı değişkenlerin tek faktörlü bir yapıda olmadıkları ve çalışmada ortak yöntem varyansı hatasının bulunmadığı saptanmıştır. Dahası, yapılar arasındaki ilişkiler karşılaştıııldığında 0.9'un üzerinde ilişkili hiçbir yapı olmadığını bulunurken, ortak yöntem yanlılığının sonuçları daha yüksek korelasyonlar üretmiş olmalıydı (r>0.90) (Podsakoff \& Organ, 1986). Bu da ortak yöntem yanlılığının önemli bir sorun teşkil etmediğini göstermektedir.

\section{BULGULAR}

Son grupta toplanan 501 katılımcının verisi üzerinden araştırma hipotezleri test edilmiştir. Araştırmada ölçüm modelinin anlamlılığ 1 ve teorik ilişkilerin test edilebilmesi için yapısal eşitlik modellemesinden (YEM) yararlanılmıştır. Ölçüm modeliyle yapıların güvenilirliği ve geçerliliği test edilirken, yapısal modelde teorik alt yapıyla oluşturulan nedensel ilişkiler yol analiziyle test edilmiştir.

Araştırmanın demografik bulgularında katılımcıların \%54,1'i erkek ve \%45,9'u kadındır. 501 örneklemin \%38,9'u 17-29 yaş grupları arasında yer almaktadır. Dolayısıyla örneklemin büyük bir çoğunluğunun genç nüfus olduğu görülmektedir. Katılımcıların eğitim durumlarına bakıldığında 356 kişinin üniversite mezunu olduğu görülmektedir. Katılımcıların yılda çıkılan seyahat sayıları incelendiğinde \%76,6'sının 0 ile 5 sayı grubu aralığında oldukları, \%72,5'inin 0-5 yıllık çevrimiçi seyahat aracıları ve seyahat sitelerinin kullanım süreleri gibi bir yüzdeye sahip oldukları görülmektedir. Turizm ürün ve hizmetleri ile ilgili internet kullanım durumu incelendiğinde; interneti sadece bilgi amaçlı kullanım yüzdesi \%38,9 iken, turizm ürün ve hizmetleri ile ilgili her türlü işlemi (satın alma dâhil) internet üzerinden yapan kişi yüzdesi \%61,1'dir. Sosyal medya türleri ve seyahat siteleri kullanımlarında, en fazla kullanım ortalamasına sahip sosyal medya türünün 4,890 ile Instagram olduğu görülmekle beraber Facebook 
kullanım ortalamasının 3,292, Twitter kullanım ortalamasının 2,472 ve çevrimiçi seyahat aracıları ve seyahat siteleri (Online Travel Agency-OTA, Metasearch Engine-META) kullanım ortalamasının 3,971 olduğu görülmektedir (Tablo 3).

Tablo 3. Katılımcıların dağılımı $(\mathbf{n}=501)$

\begin{tabular}{|c|c|c|c|}
\hline Demografik & Aralık & Frekans & Yüzde (\%) \\
\hline \multirow[t]{5}{*}{ Yaş } & $17-29$ & 195 & $38.9 \%$ \\
\hline & $30-39$ & 148 & $29.5 \%$ \\
\hline & $40-49$ & 101 & $20.2 \%$ \\
\hline & $50-59$ & 41 & $8.2 \%$ \\
\hline & 60 ve üstü & 16 & $3.2 \%$ \\
\hline \multirow[t]{2}{*}{ Cinsiyet } & Erkek & 271 & $54.1 \%$ \\
\hline & Kadın & 230 & $45.9 \%$ \\
\hline \multirow[t]{3}{*}{ Eğitim Durumu } & İlkokul & 21 & $4.2 \%$ \\
\hline & Lise & 124 & $24.8 \%$ \\
\hline & Üniversite & 356 & $71.1 \%$ \\
\hline Yılda çıkılan seyahat & $0-5$ & 384 & $76.6 \%$ \\
\hline \multirow[t]{4}{*}{ say1S1 } & $6-10$ & 75 & $15.0 \%$ \\
\hline & $11-15$ & 15 & $3.0 \%$ \\
\hline & $16-20$ & 13 & $2.6 \%$ \\
\hline & 20 ve üstü & 14 & $2.8 \%$ \\
\hline Çevrimiçi seyahat & $0-5$ & 363 & $72.5 \%$ \\
\hline sitelerini kullanım & $6-10$ & 121 & $24.2 \%$ \\
\hline süresi (y1l) & 11 ve üstü & 17 & $3.4 \%$ \\
\hline Turizm ürün ve & Sadece bilgi alma amaçlı & 195 & $38.9 \%$ \\
\hline hizmetleri ile ilgili & kullanım. & & \\
\hline \multirow{4}{*}{$\begin{array}{l}\text { internet kullanım } \\
\text { durumu }\end{array}$} & Her türlü işlem (satın alma & 306 & $61.1 \%$ \\
\hline & dahil) internet üzerinden & & \\
\hline & yap1lır. & & \\
\hline & & Ortalama & Std. Sapma \\
\hline Sosyal medya türleri & Instagram & 4,916 & 2,286692 \\
\hline ve seyahat siteleri & Facebook & 3,423 & 2,295339 \\
\hline kullanım ortalaması ve & Twitter & 2,427 & 2,001295 \\
\hline std. sapmaları & $\begin{array}{l}\text { Çevrimiçi seyahat aracıları ve } \\
\text { siteleri (OTA-META) }\end{array}$ & 4,049 & 2,230584 \\
\hline Toplam katılımcı sayısı & & 501 & $100.0 \%$ \\
\hline
\end{tabular}

Değişkenler arasındaki ilişkiyi anlayabilmek için yapılan korelasyon analizi sonucunda, değişkenlerin ortalama ve standart sapma değerleri ile verilerin normal dağılımının kontrolünün sağlanması için çarpıklık ve basıklık değerleri Tablo 4'te verilmiştir. Verilerin normal dağıldığ görülmüş olup korelasyon katsayılarına bakıldığında ise genel olarak araştırma değişkenleri arasında pozitif yönlü ilişkiler tespit edilmiştir. 
Alguer \& Çizel (2021), Johti, 3(2), 153-175

Tablo 4. Betimsel istatistikler ve değişkenler arasındaki korelasyonlar

\begin{tabular}{cccccccc}
\hline & P.Mot. & İlişki K. & $\begin{array}{c}\text { Sosyal } \\
\text { D. }\end{array}$ & Ortalama & $\begin{array}{c}\text { Std. } \\
\text { Sapma }\end{array}$ & Çarpıklık & Basıklık \\
\hline $\begin{array}{c}\text { Paylaşım } \\
\text { Motivasyonu }\end{array}$ & 1 & & & $\mathbf{4 , 3 4 5 0}$ & $\mathbf{1 , 5 2 3 1 3}$ & $\mathbf{- , 2 6 6}$ &,- 558 \\
\hline Illişki Kalitesi &, $\mathbf{4 1 2}^{* *}$ & 1 & & $\mathbf{3 , 7 6 9 8}$ & $\mathbf{1 , 4 7 4 7 4}$ &, 032 &,- 721 \\
\hline Sosyal Destek & $\mathbf{, 5 2 3}^{* *}$ &, $\mathbf{5 5 6}^{* *}$ & 1 & $\mathbf{3 , 5 2 4 5}$ & $\mathbf{1 , 6 1 2 0 3}$ &, $\mathbf{1 8 4}$ & $\mathbf{- , 8 4 6}$ \\
\hline
\end{tabular}

**. Korelasyon 0,01 düzeyinde anlamlıdır.

Ölçüm modelinin anlamlılığı saptandıktan sonra kurulan hipotezler doğrultusunda oluşturulan model LISREL 8.0 ile test edilmiştir. Modellerin yorumlanmasındaki önemli bir ölçüt her bir gözlenen değişken için açıklanan varyansı ifade ederek, gözlenen değişkenin gizil değişkendeki değişimin ne kadarını açıklayabildiğini ortaya koyan $\mathrm{R}^{2}$ değeridir (Şimşek, 2007). Şekil 2'de modele ilişkin $\lambda \mathrm{x}, t$ ve $\mathrm{R}^{2}$ değerlere yer verilmiştir. Ayrıca yapısal eşitlik modelinde gizil değişkenleri gözlenen değişkenlere bağlayan standardize edilmiş değerler $\lambda x$ (Lambda-x) olarak adlandırılmakta ve ilgili gözlenen değişkenin gizil değişken açısından önemini ortaya koymaktadırlar (Şimşek, 2007). Bu değerler incelendiğinde tüm gözlenen değişkenlerin gizil değişkenin ölçümüne olumlu yönde katkı sağladığı görülmektedir.

Yapılar arasındaki ilişkileri rapor etmek için yol katsayıları Şekil 2'de gösterilmiştir. Buna göre araştırmanın tüm hipotezleri desteklenmektedir. Bulgulara göre, hem ilişki kalitesi (0.50) hem de sosyal desteğin (0.17) deneyim paylaşımı motivasyonu üzerinde olumlu etkileri vardır ve ilişski kalitesinin daha güçlü bir etkisi vardır. Sosyal destek (0.60) ilişki kalitesini olumlu yönde etkilemektedir. Elde edilen bu değerler, araştırma hipotezlerinin tümünün desteklendiğini göstermektedir.

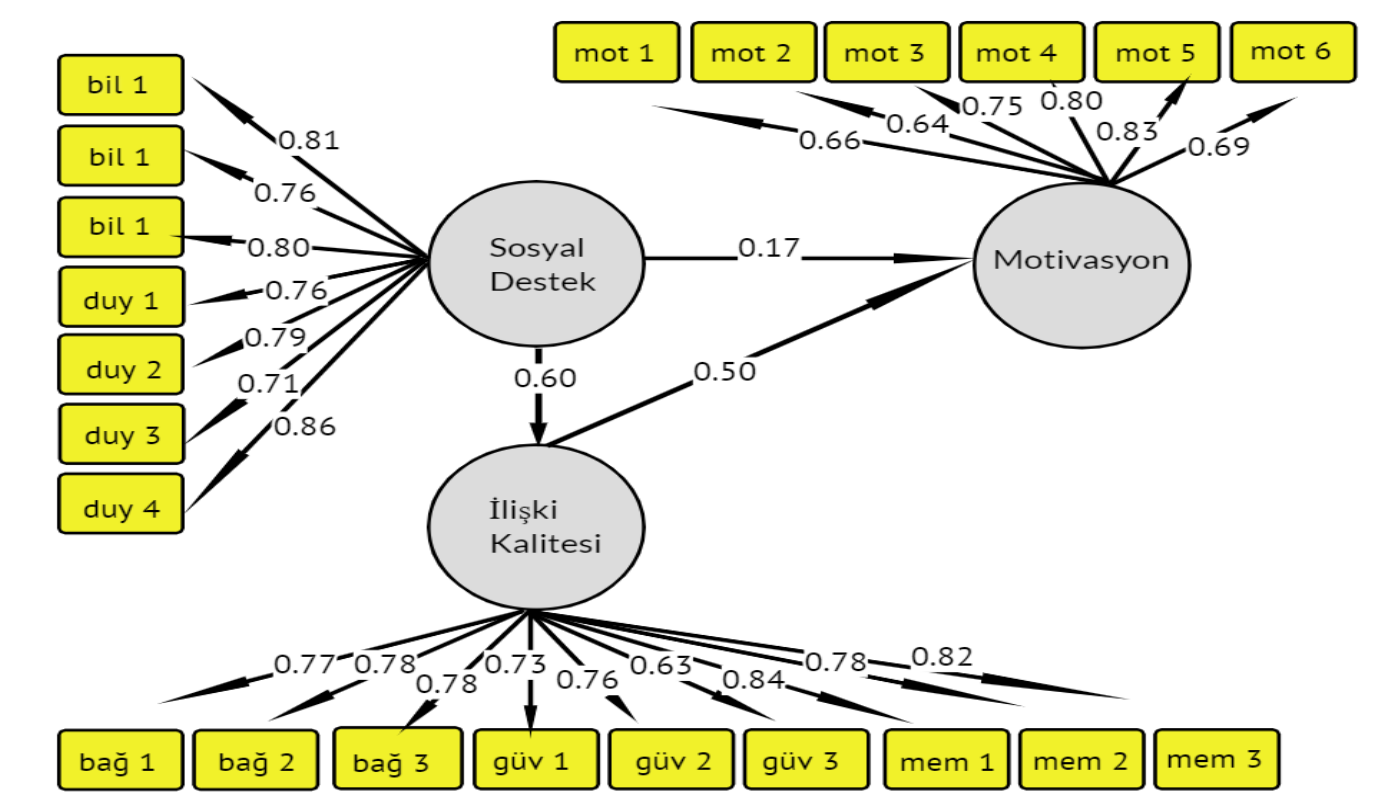

\begin{tabular}{|c|c|c|c|c|c|c|c|c|c|}
\hline & $\boldsymbol{\chi} \mathbf{2}$ & df & $\boldsymbol{\chi} \mathbf{2} / \mathbf{d f}$ & RMSEA & GFI & AGFI & CFI & TLI/NNFI & NFI \\
\hline Model & 631.56 & 197 & 3.20 & 0.066 & 0.90 & 0.87 & 0.98 & 0.98 & 0.97 \\
\hline
\end{tabular}

Şekil 2. Yapısal modele ilişkin standardize edilmiş değerlerin diyagram gösterimi

Uyum iyiliği değerleri, modelin kabul edilip edilemeyeceğine ilişkin bir takım kabul edilebilir sınır değerler kullanılarak yorumlanmaktadır. Yani analizler sonucunda üretilen uyum istatistiklerinin belli değerlerin üzerinde veya altında olması istenir. Bu noktada Şekil 2'de verilen analiz sonuçlarına genel olarak bakıldığında $\chi 2 /$ df değerinin 3,20 düzeyinde olduğu görülmektedir. Yazında bu değerin iki ile beş 
arasında olduğu modeller kabul edilebilir modeller olarak nitelendirilmektedir (Hair vd., 2014). Öte yandan model uyumunun önemli bir göstergesi olan ve kabul edilebilir bir model için 0,90 seviyesinde değer göstermesi beklenen (Hair vd., 2014). NFI değeri 0,97 olarak bulunmuştur. NFI, sınırlanmış model ile tam model arasındaki değer farkının taban çizgisi sıfır modeli kullanarak oranını ölçer ve ki-kareyi 0 ile 1 arasında bir aralıkta yeniden ölçeklendirir (Hair vd., 2014). Bulunan NFI değeri, modelin kabulünü önerir ve bu da verinin modele uyumunun genel derecesini gösterir (Aksu, Eser, \& Güzeller, 2017). TLI değeri 0,98 olarak bulunmuştur ve yazında 0,95 ve üzeri değerler kabul edilebilir olarak değerlendirilmektedir (Hair vd., 2014). GFI değeri 0,90 olarak bulunmuştur. GFI değerlerinin olası aralığ 0 ile 1'dir, daha yüksek değerler daha iyi uyduğunu gösterir. Bulunan bu değer ise yazında kabul edilir olduğunu göstermektedir gösterir (Hair vd., 2014). Modelin RMSEA değeri 0,06 olarak bulunmuştur ve yazında RMSEA değerinin 0,08'in altında olma koşullarını sağlamaktadır (Hair vd., 2014). AGFI değeri ise 0,87'dir bu ölçüt değerleri, 0,85 ve 0,90 aralığında olması beklendiği için bu değerin de kabul edilebilir bir seviyede olduğu görülmektedir (Hair vd., 2014; Aksu vd., 2017). Tüm uyum değerlerinin kabul edilebilir düzeyde oldukları gözlenmektedir (Hair vd., 2014).

\section{TARTIŞMA}

Sosyal medya aracılığıyla turizm deneyimi paylaşımı, gelecek vaat eden bir araştırma alanıdır. Birçok sektörde araştırılmış olan deneyim paylaşımı ile bilgi yoğun bir sektör olan turizm sektöründe insanların tatil deneyimlerini başkalarıyla hangi motivasyon ile paylaşmaları ve bu paylaşma motivasyonunun nelerden etkilendiğinin incelenmesi önem taşımaktadır. Deneyim paylaşma motivasyonu ve bu motivasyon ile ilişkisi olduğu düşünülen faktörlerin ilişkili olup olmadığı Türk turistler üzerinde yapılan bir araştırma ile görgül olarak ilk defa test edilmiştir. Dolayısıyla ilişkisel pazarlama teorisi ve sosyal destek teorisine dayanarak bu araştırmada literatürdeki benzer araştırmalarda olduğu gibi güven, bağl1lık ve memnuniyetten oluşan ilişki kalitesi ile turizm deneyimlerini sosyal medya aracılığıyla paylaşma motivasyonu arasında pozitif ve anlamlı bir ilişki tespit edilmiştir (Munar \& Jacobsen, 2014; Hsu vd., 2007).

İlişki kalitesinin temel olarak üç yönü olduğunu bilinmektedir ve bunlar; güven, memnuniyet ve bağl1lıktır (Wulf vd., 2001). Bireysel ve toplumla ilgili motivasyonlar açısından önceki çalışmalara göre insanlar, forumlara ve topluluklara katılmaya, deneyimlerini, bilgilerini paylaşmaya ve bu topluluklardaki güven, memnuniyet ve bağlılık duygularını algıladıkça, diğer insanlara tavsiye ve bilgilerini paylaşmaya isteklidirler (Hajli, 2014). Bu durum sanal ortamlarda güven, ilişki bağlılığ ve ilişki memnuniyeti olan turistlerin daha sağlıklı deneyim paylaşımları sağlayacağı sonucuyla tutarlı olarak ifade edilebilmektedir.

Sosyal destek bilgi desteği ve duygusal destek gibi birçok özelliği olan (örneğin; maddi destek, sayg1 desteği vb.) bir kavramdır ve bu araştırmada sadece iki yönü ele alınmıştır. Sosyal medya açısından bakıldığında bazı sosyal medya türleri, bünyesinde bulunan üyelerine nesnelerin (yorum, fotoğraf, müzik, video vb. gönderiler gibi) kaç kez işaretlendiğini söyleyen "sosyal paylaşım ikonları" olarak adlandırılan "beğen", "paylaş", "takip et" ve "abone ol" butonları gibi kalite çıkarım işlevlerini içermektedirler. Bunlar bilgilendirici ve duygusal destek sağlamaktadırlar (Gerlitz \& Helmond, 2013). Araştırmada sosyal desteğin turizm deneyimlerini paylaşma motivasyonları üzerindeki etkisi önceki araştırmaların bulgularıyla tutarlıdır (Wang, Park, \& Fesenmaier, 2011; Tussyadiah \& Fesenmaier, 2009; Kim \& Tussyadiah, 2013).

Sosyal destek aynı zamanda ilişki kalitesini de etkiler. Bu bulgu çevrimiçi ağlarda, kullanıcıların birbirleriyle destek alışverişinde bulunabilecekleri onaylar. Önceki araştırmalarda da çevrimiçi ağlarda bireylerin ilişkisinin ve sosyal desteğin mevcudiyeti, ağa güven (Zaglia, 2013) sağladığı ve kullanıcılara memnuniyet sağladığ 1 (Obst \& Stafurik, 2010) tespit edilmiştir. 
Birçok insan arkadaşlarıyla rahat bir şekilde etkileşimde bulunma beklentisiyle bir sosyal ağ topluluğuna katılır. Böyle bir destekleyici ilişki olmasaydı, ilişki kalitesi (ilişkisel anlamda güven, ilişkiyi sürdürme çabası anlamında bağlılık ve sürdürülen ilişkiden duyulan memnuniyet) için motivasyon azalacaktır. Sosyal psikolojiden kaynaklanan "aktarım" olgusu (Andersen \& Baum, 1994) kişinin, geçmiş ilişkilerinin (deneyimlerin) etkilerini gelecekteki ilişkilerine aktarma eylemini ifade etmektedir (Chen \& Andersen, 1999). Turistler de yaşadıkları tatilin etkilerini, kolaylıklarını, zorluklarını ve sosyal medyaya aktarabilecekleri tüm konuları karşıdaki alıcılar ile ilişkilerinde bilgisel destek ve duygusal destek sunmak amacıyla paylaşmaktadırlar. Sosyal medyada bu destekleyici paylaşımlar ancak ilişkisel bağl1lık, güven ve bu ilişkiden duyulan memnuniyet olduğu zaman gerçekleşmektedir. Araştırmada yer alan son hipotez, turistlerin üç ilişki kalitesi boyutunun (güven, bağlılık ve memnuniyet) etkisiyle destekleyici paylaşımlarda bulunduklarını betimler niteliktedir. Dolayısıyla son bulgu olan sosyal desteğin ilişki kalitesini etkilemesi Hajli, Sims, Zadeh \& Richard (2017) ile Liang vd.'nin (2011) araştırmalarında varılan sonuçlarla tutarlılık göstermektedir.

\subsection{Teorik Katkılar}

İlk olarak turistlerin sosyal medyada deneyimlerini paylaşma motivasyonunun iki ana grupta toplandığı ve bunların: bireysel motivasyonlar ve sosyal motivasyonlar oldukları doğrulanmıştır. Bireysel motivasyonlar; bireylerin sonuç beklentileri temelinde, sosyal ilişkiler kurma becerileri, özyeterlilik temelinde; bireylerin kendi kendilerine yetebilmeleri (Bandura, 1978), empati kurabilmeleri (Bandura, 1978) ve benmerkezli olma temelinde; kişisel tatmin, kendini gerçekleştirme, başkalarının kendisi hakkında düşünmelerini sağlamayı ifade etmektedir (Jinyang, 2015; Wilcox vd., 2006; Yoo \& Gretzel, 2008). Sosyal motivasyonlar ise; bireylerin başkalarına doğru kararlar vermelerinde yardımcı olmayı, kötü ürün/hizmet tercih etmelerini engellemeyi, faydalı ve değerli olduğu düşünülen konularda katkıda bulunmalarını ifade etmektedir (Munar \& Jacobsen, 2014; Ma \& Chan, 2014). Ayrıca turistlerin sanal platformlara aktardıkları içerikler, ister benmerkezli motivasyonla isterse başkalarına yardımcı olmak amacıyla sosyal motivasyonla paylaşılsın her ikisi de insanların sosyal ağlara farklı motivasyonlarla katıldıklarının göstergesidir (Munar \& Jacobsen, 2014).

Çevrimiçi ağlar veya sosyal medya için temel amaç ilişki kurmaktır (Yoo \& Gretzel, 2008). Dolayısıyla turizmde, turistik ürün/hizmet deneyimi yaşayan turistler, birbirleriyle etkileşime girerek edindikleri duygu ve düşünceleri diğer turistlerle bu iki (bireysel, sosyal) motivasyonun etkisiyle sosyal medyada paylaşmaktadırlar (Munar \& Jacobsen, 2014). Turistler deneyim paylaşımlarında bulunurken bensever (egoizm) ve elsever (alturizm) davransalar da bu paylaşımlarıyla, etkileşimde oldukları ağlar üzerinden destek alarak ve oluşturdukları ilişkileri koruyarak devam ettirme niyetindedirler (Lai \& Chen, 2014; Pan, Maclaurin, \& Crotts, 2007). Dolayısıyla sosyal medyada turizm deneyimini paylaşma motivasyonunu etkileyen faktörlerin yordanmaya çalışıldığı bu araştırmada, turistlerin deneyim paylaşma motivasyonları ve onların sosyal ağlarındaki insanlarla kurdukları ilişki kalitesi ve sosyal destek ile anlamlı bir ilişkisinin olduğu ortaya koyulmaktadır.

\subsection{Yönetimsel Katkılar}

Turistlerin sosyal medya platformlarını nasıl kullandıkları ve davranışlarının turizm deneyimlerinin tüm aşamalarında (planlama, tatil aşaması ve tüketim sonrası) üretilen içeriklerin ve deneyim paylaşımlarının, turizm sağlayıcılarının yönetim ve pazarlama fonksiyonları üzerinde önem arz etmektedir. Bilgi teknolojisinin ve sosyal medya teknolojilerinin hızla gelişmesinin, turizm endüstrisi üzerinde derin etkileri vardır. Bu araştırma, turizm literatürü destekleyerek ve genişleterek uygulayıcılar bağlamında fayda sağlamaktadır. Çünkü turizm sektöründeki paydaşları yakından ilgilendiren bir konu olan sosyal medyada deneyim paylaşımının ve paylaşımda bulunmayı etkileyen unsurların önemi ortaya koyulmaya çalışılmıştır. Bulgular Türk turistler ile çalışan turizm sektöründeki işletmelerini yakından 
ilgilendirmektedir. Türk turistlerin turizm deneyimlerini sosyal medyada paylaşma motivasyonunu etkileyen faktörlerin bilinmesi önemli faydalar sağlayabilir. Turizm sağlayıcıları, çeşitli yönetim, pazarlama ve işlev süreçlerinde turistlerin sosyal medya incelemelerini ve deneyim paylaşımlarını kullanabilirler. Sosyal medyanın tüm avantajlarından yararlanmak için turizm sağlayıcılarının sosyal medya kullanımını yönetsel ve dijital pazarlama faaliyetlerine dâhil etmesi gerekmektedir. Öte yandan, sektör uygulamacıları sosyal medyanın, turistlere deneyim paylaşmalarına ilham vermek için katkı sürecini geliştirerek minimum maliyetle daha fazla katkı içeriği elde etmesi beklenmektedir. Uygulamada; deneyim paylaşımını motive etmenin etkili yolları olduğu düşünülen bonus puan, hediye eğlence paketleri, indirim/promosyon, ücretsiz deneyim turu veya diğer maddi ödüllere sahip deneyim paylaşımcısı turistler ile karşılıklı ilişki oluşturulabilir. Deneyim paylaşmayı seven turizm tüketicilerine, turizm uygulamacıları sosyal medya üzerinden daha fazla odaklanmalı, onların sağladığı bilgilerin kalitesini artırarak tüketici memnuniyetini, sosyal medya kalitesini ve web sitesi güvenilirlik algılarını geliştirmelidirler. Bu sayede etkileşime girmeyi seven tüketiciyle işletmeler tanınırlıklarını ve sektördeki etkilerini artırabilirler.

Turizm sektöründe tüketiciler reklam verenlerin pazarlama mesajlarından çok sosyal ağlarındaki topluluklara daha fazla güvenmektedirler (Kim \& Tussyadiah, 2013). Bu durum araştırmada ulaşılan bulgular 1şı̆̆ında değerlendirildiğinde gerçekten de turistlerin bir turizm ürün ve hizmetini satın almak için başkalarının çevrimiçi önerilerini ve değerlendirmelerini kullandıklarını göstermektedir. Bilgi aramalarının satın alma karar sürecinin önemli bir parçası olması sosyal medyadan elde edilen seyahat bilgisi sadece ilgili belirsizliği ve algılanan riskleri azaltmakla kalmaz, aynı zamanda seyahatlerin kalitesini de artırır. Ayrıca günümüzde sosyal ağlar, turizm tüketicilerini çevrimiçi olarak bilgi yayan, gazeteci, muhabir, sosyal danışman gibi hareket etmelerini mümkün kılmaktadır.

Kullanıcı tarafından üretilen içeriğin hızlı bir şekilde büyümesi işletmecilerden tüketicilere olan güç dengesini değiştirmektedir. Nitekim bu araştırmada da yer alan bulgularda olduğu gibi elektronik ağızdan ağıza iletişimi (e-wom) sosyal medya ile deneyim paylaşımında kullanan bir turist, turizm ürünleri üzerinde hem olumlu hem de olumsuz etki gösterebilme potansiyele sahip olmaktadır. Bu açıdan bir turistin kendi sosyal medya hesabından anlık olarak olumlu veya olumsuz bilgi sağlayabilmesi dikkate alınmalıdır. Yöneticilerin bu durum karşısında hazırlıklı olmaları ve sosyal medya ile ilgilenen departmanlarına gerekli eğitim ve yönlendirmeler ile kendi işletmeleri haklarında oluşabilecek bir deneyim paylaşımını (yorum, fotoğraf, video vb.) fark ederek bu içeriğin sağlayıcısı olan turist ile iletişim kurabilmelidirler. Ayrıca sosyal medya siteleri yöneten uygulayıcıların sadece web sitesinde nasıl iyi hizmetler sunacaklarını değil, aynı zamanda ilgili topluluklarda destekleyici bir ortamı nasıl düzenleyeceklerini de dikkate almaları önem arz etmektedir. Bu durum, turizm tüketicilerinin edindikleri deneyimleri kendi çevreleriyle çevrimiçi olarak paylaşımda bulunma davranışlarını arttırması şeklinde yorumlanabilir.

\subsection{Araştırmanın Sınırlııkları ve Gelecek Çalışmalar için Öneriler}

Turistlerin sosyal medya ile deneyim paylaşım davranışları ülke ve kültürlere göre farklılık gösterebilmektedir. Bu bağlamda farklı ülke ve kültürlerden turistlerin sosyal medya ile turizm deneyimi paylaşımını etkileyen faktörler karşılaştırmalı olarak incelenebilir.

Birçok araştırmada olduğu gibi bu araştırmada da bazı sınırlılıklar bulunmaktadır. Araştırma kapsamında Antalya'yı ziyaret eden Türk turistlerden kolayda örnekleme yöntemi ile bir çalışma grubu oluşturulmuştur. Farklı demografik yapıya sahip yerli ve yabancı turistlerle de sosyal medya ile deneyim paylaşımı üzerine çalışmalar yapılması ilgili literatüre katkı sağlayabilir. Ayrıca gelecekteki araştırmalar, turizm bağlamında sosyal medya ile deneyim paylaşımının yordayıcısı olan farklı bireysel ve sosyal faktörleri inceleyebilirler. 
Başka bir sınırlama ölçüm aracına ait sınırlamadır. Anket toplama işleminde dikkat edilse dahi katılımcıların söyledikleri ile davranışları aynı olmayabilir ve sonuç gerçek katılımcı davranışından farklı olabilir. Bu durum, anket çalışmalarının ve daha doğrusu ölçüm araçlarının doğasında var olan sınırlamadır. Son olarak bu çalışmadaki örtük değişkenler arası ilişkiler nicel araştırma yöntemleri kullanılarak sunulmuştur. Konunun daha derinlemesine incelenebilmesi ve değişkenler arasındaki ilişkilerin nasıl ve neden ortaya çıktığının açıklanabilmesi açısından benzer çalışmalar nitel araştırma yöntemleri veya karma araştırma yöntemleri aracılığıyla da yapılabilir.

\section{SONUÇ}

Çevrimiçi bilgi/deneyim paylaşımı literatüründen ve sosyal destek, ilişki kalitesi teorilerinden yararlanarak, turistlerin deneyim paylaşma motivasyonlarının hangi unsurlardan etkilendikleri araştırılmıştır. Bu makale, turistlerin deneyim paylaşma motivasyonları ve çevrimiçi ağlardaki insanlarla kurulan ilişkilerde hangi faktörlerin paylaşım yapma noktasında etkili olması açısından iyi bir anlayış sağlar. Bulgular, turizm sağlayıcıları açısından araçsal içgörüler sağlar. Uygulamacılar çeşitli yönetim, pazarlama ve işlev süreçlerinde turistlerin sosyal medya incelemelerini ve deneyim paylaşımlarını kullanabilirler. Sosyal medyanın avantajlarından yararlanmak için turizm sağlayıcılarının sosyal medya kullanımını yönetsel ve dijital pazarlama faaliyetlerine dâhil etmesi gerekmektedir. Bulgular, sosyal medya kullanımı ile turizm deneyimi paylaşımı konusunda tüketici davranışı üzerindeki etkileri araştırmakla ilgilenen araştırmacılara yardımcı olabilir. Ayrıca araştırmacılar, çevrimiçi turizm deneyimi paylaşma motivasyonlarını literatürde yer alan değişkenlerle ilişkilendirebilir ve farklı etkileri keşfedebilirler.

\section{KAYNAKÇA}

Akbıyık, A., \& Coşkun, E. (2013). Eğitsel sosyal yazılımların kabul ve kullanımına yönelik bir model. Online Academic Journal of Information Technology, 4(13), 39-62.

Aksu, G., Eser, M. T., \& Güzeller, C. O. (2017). Açımlayıcı ve doğrulayıcı faktör analizi ile yapısal eşitlik modeli uygulamaları (1. Baskl). Ankara: Detay Yayıncılık.

Andersen, S. M., \& Baum, A. (1994). Transference in interpersonal relations: Inferences and affect based on significant-other representations. Journal of Personality, 62(4), 459-497.

Anderson, S. L., \& Betz, N. E. (2001). Sources of social self-efficacy expectations: Their measurement and relation to career development. Journal of Vocational Behavior, 58(1), 98-117.

Bagozzi, R. P., \& Dholakia, U. M. (2002). Intentional social action in virtual communities. Journal of Interactive Marketing, 16(2), 2-21.

Balc1, A. (2004). Sosyal bilimlerde araştırma yöntem, teknik ve ilkeler. Ankara: Pegem Akademi Yayınc1lik.

Bandura, A. (1978). Self-efficacy: Toward a unifying theory of behavioral change. Advances in Behaviour Research and Therapy, 1(4), 139-161.

Bandura, A. (2006). Guide for constructing self-efficacy scales. İçinde T. Urdan, \& F. Pajares (Ed.), Self-efficacy beliefs of adolescents (s. 307-337). Charlotte, North Carolina, U.S.: Information Age Publishing.

Baş, F. C. (2018). Sosyal medya davranışının oluşumu: Çevrimiçi ortamlarda güven, sosyal sermaye ve saygınlık ilişkisi. Sosyoloji Araştırmaları Dergisi, 21(2), 49-85.

Baym, N. K. (2015). Personal connections in the digital age. Cambridge, UK: Polity Press.

Berger, J., \& Schwartz, E. M. (2011). What drives immediate and ongoing word of mouth? Journal of Marketing Research, 48(5), 869-880. 
Berry, L. L. (1983). Relationship marketing in emerging perspectives on services marketing. Chicago: American Marketing Association.

Büyüköztürk, Ş. (2011). Sosyal bilimler için veri analizi el kitabı istatistik, araştırma deseni spss uygulamaları ve yorumu (14.baskl). Ankara: Pegem Akademi Yayıncılık.

Caprara, G. V., \& Steca, P. (2005). Self-efficacy beliefs as determinants of prosocial behavior conducive to life satisfaction across ages. Journal of Social and Clinical Psychology, 24(2), 191-217.

Casaló, L. V., Flavián, C., \& Guinalíu, M. (2008). Promoting consumer's participation in virtual brand communities: A new paradigm in branding strategy. Journal of Marketing Communications, 14(1), 19-36.

Chang, H. H., \& Chuang, S.-S. (2011). Social capital and individual motivations on knowledge sharing: Participant involvement as a moderator. Information \& Management, 48(1), 9-18.

Chen, J., Xu, H., \& Whinston, A. B. (2011). Moderated online communities and quality of usergenerated content. Journal of Management Information Systems, 28(2), 237-268.

Chen, S., \& Andersen, S. M. (1999). Relationships from the past in the present: Significant-other representations and transference in interpersonal life. Advances in Experimental Social Psychology, 31, 123-190.

Chiu, C.-M., Hsu, M.-H., \& Wang, E. T. (2006). Understanding knowledge sharing in virtual communities: An integration of social capital and social cognitive theories. Decision Support Systems, 42(3), 1872-1888.

Coulson, N. S. (2005). Receiving social support online: An analysis of a computer-mediated support group for individuals living with irritable bowel syndrome. CyberPsychology \& Behavior, 8(6), 580584.

Crocker, J., \& Canevello, A. (2008). Creating and undermining social support in communal relationships: The role of compassionate and self-1mage goals. Journal of Personality and Social Psychology, 95(3), 555-575.

Eralp, Z. (1983). Genel turizm. Ankara: Ankara Üniversitesi Basın - Yayın Yüksek Okulu Yayınları.

Fornell, C., \& Larcker, D. F. (1981). Evaluating structural equation models with unobservable variables and measurement error. Journal of Marketing Research, 18(1), 39-50.

Garbarino, E., \& Johnson, M. S. (1999). The different roles of satisfaction, trust, and commitment in customer relationships. Journal of Marketing, 63(2), 70-87.

Gerlitz, C., \& Helmond, A. (2013). The like economy: Social buttons and the data-intensive web. New Media \& Society, 15(8), 1348-1365.

Ghaisani, A. P., Handayani, P. W., \& Munajat, Q. (2014). Users' motivation in sharing information on social media. Procedia Computer Science, 124, 530-535.

Göker, G., \& Keskin, S. (2015). Sosyal medya türevi olarak sosyal içerik platformları: Betimsel bir inceleme social content platforms as a social media type: A descriptıve review. Uluslararasi Sosyal Araştırmalar Dergisi, 8(39), 861-874.

Gretzel, U., \& Yoo, K.-H. (2008). Use and impact of online travel reviews. Information and Communication Technologies in Tourism (s. 35-46). Veinna, Austria: Springer.

Gustafsson, A., Johnson, M., \& Roos, I. (2005). The effects of customer satisfaction, relationship commitment dimensions, and triggers on customer retention. Journal of Marketing, 69, 210-218.

Hair, J. F., Black, W. C., Babin, B. J., \& Anderson, R. E. (2014). Multivariate data analysis. Edinburgh Gate/Harlow, United Kingdom: Pearson.

Hajli, M. N. (2014). The role of social support on relationship quality and social commerce. Technological Forecasting and Social Change, 87, 17-27. 
Hajli, N., Sims, J., Zadeh, A. H., \& Richard, M.-O. (2017). A social commerce investigation of the role of trust in a social networking site on purchase intentions. Journal of Business Research, 71, 133141.

Hargittai, E., \& Shafer, S. (2006). Differences in actual and perceived online skills: The Role of gender. Social Science Quarterly, 87(2), 432-448.

Hsu, C.-L., \& Lin, J. C.-C. (2008). Acceptance of blog usage: The roles of technology acceptance, social influence and knowledge sharing motivation. Information \& Management, 45(1), 65-74.

Hsu, M. H., Ju, T. L., Yen, C.-H., \& Chang, C.-M. (2007). Knowledge sharing behavior in virtual communities: The relationship between trust, self-efficacy, and outcome expectations. International Journal of Human-Computer Studies, 65(2), 153-169.

Huang, J., \& Hsu, C. H. (2009). The impact of customer-to-customer interaction on cruise experience and vacation satisfaction. Journal of Travel Research, 49(1), 79-92.

Huang, Y., Basu, C., \& Hsu, M. K. (2019). Exploring motivations of travel knowledge sharing on social network sites: An empirical investigation of U.S. College Students. Journal of Hospitality Marketing \& Management, 19(7), 717-734.

Jacobsen, J. K. (2000). Anti-tourist attitudes: Mediterranean charter tourism. Annals of Tourism Research, 27(2), 284-300.

Jaiswal, A. K., Niraj, R., \& Venugopal, P. (2010). Context-general and context-specific determinants of online satisfaction and loyalty for commerce and content sites. Journal of Interactive Marketing, 24(3), 222-238.

Jinyang, L. (2015). Knowledge sharing in virtual communities: A social exchange theory perspective. Journal of Industrial Engineering and Management, 8(1), 170-183.

Jöreskog, K., \& Sörbom, D. (1998). LISREL 8: Structural equation modeling with the SIMPLIS command language. United States of America: Scientific Software International.

Kankanhalli, A., Tan, B. C., \& Wei, K.-K. (2005). Contributing knowledge to electronic knowledge repositories : An empirical investigation. MIS Quarterly: Management Information Systems, 29(1), 113-143.

Kim, J. \& Tussyadiah, I. P. (2013). Social networking and social support in tourism experience: the moderating role of online self-presentation strategies. Journal of Travel \& Tourism Marketing, 30(12), 78-92.

Kim, J. (., Fesenmaier, D. R., \& Johnson, S. L. (2013). The effect of feedback within social media in tourism experiences, Design, User Experience, and Usability. Web, Mobile, and Product Design (s. 212-220). Berlin: Springer.

Kline, P. (1993). An easy guide to factor analysis. London: Routledge.

Lai, H.-M., \& Chen, T. T. (2014). Knowledge sharing in interest online communities: A comparison of posters and lurkers. Computers in Human Behavior, 35, 295-306.

Lakey, B., \& Cohen, S. (2000). Social support measurement and intervention: A guide for health and social scientists. İçinde S. Cohen, L. G. Underwood, \& B. H. Gott (Ed.), Social Support Theory and Measurement (s. 29-52). New York, NY, US: Oxford University Press.

Laurenceau, J.-P., Barrett, L. F., \& Pietromonaco, P. R. (1998). Intimacy as an interpersonal process: The importance of self-disclosure, partner disclosure, and perceived partner responsiveness in interpersonal exchanges. Journal of Personality and Social Psychology, 74(5), 1238-1251.

Liang, T.-P., Ho, Y.-T., Li, Y.-W., \& Turban, E. (2011). What drives social commerce: The role of social support and relationship. International Journal of Electronic Commerce, 16(2), 69-90. 
Luo, Q., \& Zhong, D. (2015). Using social network analysis to explain communication characteristics of travel-related electronic word-of-mouth on social networking sites. Tourism Management, 46, 274282.

Ma, W. W., \& Chan, A. (2014). Knowledge sharing and social media: Altruism, perceived online attachment motivation, and perceived online relationship commitment. Computers in Human Behavior, 39, 51-58.

Maier, C., Laumer, S., Eckhardt, A., \& Weitze, T. (2015). Giving too much social support: Social overload on social networking sites. European Journal of Information Systems, 24(5), 447-464.

Major, D. A., Kozlowski, S. W., Chao, G. T., \& Gardner, P. D. (1995). A longitudinal investigation of newcomer expectations, early socialization outcomes, and the moderating effects of role development factors. Journal of Applied Psychology, 80(3), 418-431.

Malhotra, N. K., Kim, S. S., \& Agarwal, J. (2004). Internet users' information privacy concerns (IUIPC): The construct, the scale, and a causal model. Information Systems Research, 15(4), 336-355.

Maslow, A. H. (1943). A theory of human motivation. Psychological Review, 50(4), 370-396.

Moorman, C., Deshpandé, R., \& Zaltman, G. (1993). Factors affecting trust in market research relations. Journal of Marketing, 57(1), 81-101.

Morgan, R. M., \& Hunt, S. (1994). The commitment-trust theory of relationship marketing. Journal of Marketing, 58(3), 20-38.

Munar, A. M., \& Jacobsen, J. K. (2013). Trust and involvement in tourism social media and web-based travel information sources. Scandinavian Journal of Hospitality and Tourism, 13(1), 1-19.

Munar, A. M., \& Jacobsen, J. K. (2014). Motivations for sharing tourism experiences through social media. Tourism Management, 43, 46-54.

Munar, A. M., \& Ooi, C.-S. (2012). The truth of the crowds: Social media and the heritage experience. İçinde L. Smith, E. Waterton, \& S. Watson (Ed.), The Cultural Moment in Tourism (Advances in Tourism) (s. 255-273). New York: Routledge.

Nunnally, J., \& Bernstein, I. (1994). Psychometric theory. New York: McGraw-Hill.

Obst, P. L., \& Stafurik, J. (2010). Online we are all able bodied: Online psychological sense of community and social support found through membership of disability-specific websites promotes well-being for people living with a physical disability. Journal of Community \& Applied Social Psychology, 20(6), 525-531.

Oh, H. J., Ozkaya, E., \& LaRos, R. (2014). How does online social networking enhance life satisfaction? The relationships among online supportive interaction, affect, perceived social support, sense of community, and life satisfaction. Computers in Human Behavior, 30, 69-78.

Özbay, Y., Palancı, M., Kandemir, M., \& Çakır, O. (2012). Üniversite öğrencilerinin öznel iyi oluşlarının duygusal düzenleme, mizah, sosyal öz-yeterlik ve başaçıkma davranışları ile yordanması. Türk Ĕgitim Bilimleri Dergisi, 10(2), 325 -345.

Palmatier, R., Dant, R. P., Grewal, D., \& Evans, K. R. (2006). Factors influencing the effectiveness of relationship marketing: A meta-analysis. SSRN Electronic Journal, 70(4), 136-153.

Pan, B., Maclaurin, T., \& Crotts, J. C. (2007). Travel blogs and the 1mplications for destination marketing. Journal of Travel Research, 46(1), 35-45.

Pentina, I., Gammoh, B. S., Zhang, L., \& Mallin, M. (2013). Drivers and outcomes of brand relationship quality in the context of online social networks. International Journal of Electronic Commerce, 17(3), 63-86.

Podsakoff, P. M., \& Organ, D. W. (1986). Self-reports in organizational research: Problems and prospects. Journal of Management, 12(4), 531-544. 
Podsakoff, P. M., MacKenzie, S. B., Lee, J.-Y., \& Podsakoff, N. P. (2003). Common method biases in behavioral research: A critical review of the literature and recommended remedies. Journal of Applied Psychology, 88(5), 879-903.

Rotter, J. B. (1967). A new scale for the measurement of interpersonal trust. Journal of Personality, 35(4), 651-665.

Schermelleh-Engel, K., Moosbrugger, H., \& Müller, H. (2003). Evaluating the fit of structural equation models: Tests of significance and descriptive goodness-of-fit measures. Methods of Psychological Research Online, 8(2), 23-74.

Shumaker, S. A., \& Brownell, A. (2010). Toward a theory of social support: Closing conceptual gaps. Journal of Social Issues, 40(4), 11 - 36.

Sigmund, F. (2017). Kitle psikolojisi. (K. Şipal, Çev.) İstanbul: Say Yayınları.

Şimşek, Ö. F. (2007). Yapısal eşitlik modellemesine giriş - temel ilkeler ve LISREL uygulamaları (1. Baskl). Ankara: Ekinoks Yayınları.

Stanley, W., \& Faust, K. (1994). Networks, Relations and Structure. İçinde W. Stanley, \& K. Faust (Ed.), Social Network Analysis: Methods and Applications (s. 1-27). Cambridge, United Kingdom: Cambridge University Press.

Styvén, M. E., \& Foster, T. (2017). Who am 1 if you can't see me? the "self" of young travellers as driver of eWOM in social media. Journal of Tourism Futures, 4(1), 80-92.

Sun, N., Rau, P. P.-L., \& Ma, L. (2014). Understanding lurkers in online communities: A literature review. Computers in Human Behavior, 38, 110-117.

Taylor, S., Sherman, D. K., Kim, H. S., Jarcho, J. M., Takagi, K., \& Dunagan, M. (2004). Culture and social support: Who seeks it and why? Journal of Personality and Social Psychology, 87(3), 354362 .

Tussyadiah, I., \& Fesenmaier, D. (2009). Mediating tourist experiences: Access to places via shared videos. Annals of Tourism Research, 36(1), 24-40.

Wang, D., Park, S., \& Fesenmaier, D. R. (2011). The role of smartphones in mediating the touristic experience. Journal of Travel Research, 51(4), 371-387.

Wang, X., Li, X., Li, Q., \& Peng, L. (2014). Intention of sharing travel experiences on social media: Motivations and the moderating effects of face orientation. Proceedings of the 25th Australasian Conference on Information Systems, 8th - 10th December, Auckland, New Zealand: ACIS.

Wang, Y., Yu, Q., \& Fesenmaier, D. R. (2002). Defining the virtual tourist community: 1mplications for tourism marketing. Tourism Management, 23(4), 407-417.

Wilcox, S., Castro, C. M., \& King, A. C. (2006). Outcome expectations and physical activity participation in two samples of older women. Journal of Health Psychology, 11(1), 65-77.

Wulf, K. D., Odekerken-Schröder, G., \& Iacobucci, D. (2001). Investments in consumer relationships: A cross-country and cross-1ndustry exploration. Journal of Marketing, 65(4), 33-50.

Xiang, Z., \& Gretzel, U. (2010). Role of social media in online travel information search. Tourism Management, 31(2), 179-188.

Yoo, K. H., \& Gretzel, U. (2008). What motivates consumers to write online travel reviews? Information Technology \& Tourism, 10(4), 283-295.

Zaglia, M. E. (2013). Brand communities embedded in social networks. Journal of Business Research, 66(2), 216-223. 
Yazar(lar) Hakkında/About Author(s)

Aykut Oğuz ALGUER/ aykutoguz3407@gmail.com

Aykut Oğuz Alguer doktora eğitimine Akdeniz Üniversitesi'nde devam etmektedir. Çalışma alanları olarak turist davranışı, turizm sosyolojisi ve turist psikolojisi alanlarında eğitim görmektedir.

Prof. Dr. Beykan ÇizEL/ beykan@akdeniz.edu.tr

Bilkent Üniversitesi Turizm ve Otel İşletmeciliği mezunu olan Beykan ÇİZEL, Yüksek Lisans eğitimini Turizm İşletmeciliği, Doktora eğitimi ise İşletme alanında tamamlamıştır. Yönetim ve Strateji alanında doçent olan Beykan ÇİZEL, Turizm alanında profesör unvanı almıştır. 1996 yılından beri Akdeniz Üniversitesi, Turizm Fakültesi, Turizm İşletmeciliği bölümünde öğretim üyesidir. Araştırma ilgi alanları yoğun olarak e-turizm, turist davranışıdır. Turizm alanında bilimsel dergi editörlüğünün yanında akademik ve sektörel danışmanlıklar yapmaktadır.

\section{ETIKK BEYAN FORMU}

Araştırma Desteği Bilgisi: Araştırma desteği alınmamıştır.

Etik Kurul Onay Durumu

( ) Etik kurul onayı gerekmektedir.

\begin{tabular}{|l|}
\hline \multicolumn{2}{|c|}{ Etik Kurul Raporunu Veren Kurum } \\
\hline Etik kurul raporu karar tarihi: \\
\hline ( X ) Etik kurul onayı gerekmemektedir. Nedeni aşağıda belirtilmiştir. \\
\hline (X) Veriler 2020 tarihinden önce toplandığından etik kurul izni alınmamıştır. \\
\hline ( ) Çalışmada kullanılan yöntem etik kurul izni gerektirmemektedir. \\
\hline \multicolumn{1}{|c|}{ Yazar(lar)ın Katkı Oranı } \\
\hline 1. Yazar: \%50 \\
\hline 2. Yazar \%50 \\
\hline Bilgilendirilmiş Onam Formu: Tüm taraflar kendi rızaları ile çalışmaya dâhil olmuşlardır. \\
\hline
\end{tabular}

